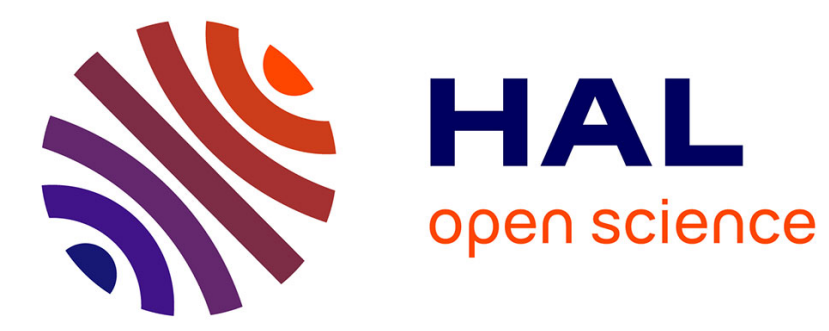

\title{
Long-term Monitoring Using Resident and Caged Mussels in BostonHarbor Yield Similar Spatial and Temporal Trends in Chemical Contamination
}

\author{
Carlton D. Hunt, Elizabeth Slone
}

\section{- To cite this version:}

Carlton D. Hunt, Elizabeth Slone. Long-term Monitoring Using Resident and Caged Mussels in BostonHarbor Yield Similar Spatial and Temporal Trends in Chemical Contamination. Marine Environmental Research, 2010, 70 (5), pp.343. 10.1016/j.marenvres.2010.07.002 . hal-00631694

\author{
HAL Id: hal-00631694 \\ https://hal.science/hal-00631694
}

Submitted on 13 Oct 2011

HAL is a multi-disciplinary open access archive for the deposit and dissemination of scientific research documents, whether they are published or not. The documents may come from teaching and research institutions in France or abroad, or from public or private research centers.
L'archive ouverte pluridisciplinaire HAL, est destinée au dépôt et à la diffusion de documents scientifiques de niveau recherche, publiés ou non, émanant des établissements d'enseignement et de recherche français ou étrangers, des laboratoires publics ou privés. 


\section{Accepted Manuscript}

Title: Long-term Monitoring Using Resident and Caged Mussels in BostonHarbor

Yield Similar Spatial and Temporal Trends in Chemical Contamination

Authors: Carlton D. Hunt, Elizabeth Slone

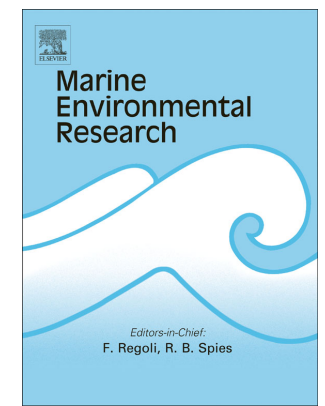

PII:

S0141-1136(10)00105-4

DOI:

10.1016/j.marenvres.2010.07.002

Reference: MERE 3464

To appear in: Marine Environmental Research

Received Date: 29 November 2006

Revised Date: 13 November 2008

Accepted Date: 15 July 2010

Please cite this article as: Hunt, C.D., Slone, E. Long-term Monitoring Using Resident and Caged Mussels in BostonHarbor Yield Similar Spatial and Temporal Trends in Chemical Contamination, Marine Environmental Research (2010), doi: 10.1016/j.marenvres.2010.07.002

This is a PDF file of an unedited manuscript that has been accepted for publication. As a service to our customers we are providing this early version of the manuscript. The manuscript will undergo copyediting, typesetting, and review of the resulting proof before it is published in its final form. Please note that during the production process errors may be discovered which could affect the content, and all legal disclaimers that apply to the journal pertain. 
Long-term Monitoring Using Resident and Caged Mussels in Boston Harbor Yield Similar Spatial and Temporal Trends in Chemical Contamination

Carlton D. Hunt and Elizabeth Slone

Battelle, 397 Washington Street, Duxbury, MA 02332

\begin{abstract}
Measurements of chemical contaminants in caged (transplanted) and resident mussel populations have become a routine tool for monitoring and assessing the status and trends of coastal water quality. However, few long-term data sets are available to assess the comparability and efficacy of these two monitoring approaches. Three long-term independent data sets exist for Boston Harbor: the National Mussel Watch program has analyzed resident blue mussels (Mytilus edulis) from the Boston Harbor/Massachusetts Bay region for over twenty years, the Massachusetts Water Resources Authority has annually deployed caged (transplanted) mussels (Mytilus edulis) to assess bioaccumulation potential of sewage effluent discharged under its NPDES permit for over fourteen years, and the GulfWatch program has analyzed resident blue mussel populations for over twelve years. Together, these data provide consistent and comparable information on temporal and spatial changes in chemical contamination in Boston Harbor as steps were taken to reduce contaminant loading. The data also demonstrate the complementary nature of resident and caged (transplanted) mussels for assessing contaminant trends even when the basic approaches and sampling frequency differ. These fifteen year data sets demonstrate contaminant concentrations in mussels from Boston Harbor are similar and with few exceptions have significantly decreased
\end{abstract}


since the early 1990s. The observed trends also demonstrate broad scale improvements to the quality of Boston Harbor and expand understanding of the response of coastal systems to interventions that reduce the load of chemicals to the ocean.

Keywords: Mussel Watch, NOAA, GulfWatch, Status and Trends, caged mussels, transplanted mussels, indigenous, resident, Boston Harbor, PAH, PCB, DDT, Chlordane, mercury, lead

\subsection{Introduction}

O'Connor and Lauenstein (2006) report that data from annual collections and chemical analyses of bivalves collected from Untied States waters between 1986 and 2003 show the national median concentrations of synthetic organic chemicals, cadmium and high molecular weight polynuclear aromatic hydrocarbon (PAH) have generally decreased. The long-term data from the Mussel Watch program from 1986 through 2005 also reveal national, regional and local trends (Kimbrough et al., 2008). One of the local areas that received significant national attention in the late 1980s is Boston Harbor. Since then the Massachusetts Water Resources Authority (MWRA), the agency responsible for water supply and treatment of sewage for metropolitan Boston has completed several facility upgrades that improve the quality of sewage discharged to this system. These include termination of sewage sludge discharge in 1991, construction and operation of advanced primary treatment facilities since 1995, completing of advanced secondary treatment facilities in 2002, and relocation of the sewage effluent discharge 9.5 miles offshore in 
Massachusetts Bay (Werme and Hunt 2006; Rex et al. 2002). Over 95 percent of the sewage discharged from this outfall receives secondary treatment.

The MWRA has also monitored the waters and sediments of Boston Harbor and Massachusetts Bay for trends in anthropogenic and other chemicals since the early 1990s (Tucker et al. 2006, Maciolek et al. 2006, Taylor 2005). Several studies have documented major improvements to the water and sediment quality (Hunt et al. 2006, Hunt et al. 2005, Bothner and Butman 2007, Zago et al. 2001, Bothner et al. 1998). One element of this long-term monitoring program is annual measurement of contaminants in the blue mussel Mytilus edulis, the same species sampled by the Mussel Watch program in the area. This paper compares nearly 20 years of transplanted and resident Boston Harbor mussels chemical monitoring in those two programs, each with their own sampling sites and protocols. Despite these program differences, downward trends in chemical concentrations of PAH, PCB, DDT, Chlordane, and lead attributable to changes in wastewater treatment and other contaminant loading over this period are observed.

\subsection{Background}

MWRA deploys the mussels in cages in the water column at strategic locations in Boston Harbor as well as Massachusetts and Cape Cod Bays (Figure 1). Some of the MWRA stations are in relatively close proximity (3-4 Km separation) to the Mussel Watch stations (Figure 1) which sample shoreline locations bay wide; however, some of the Mussel Watch and MWRA stations are separated by geographic features such as land masses or longer distances ( $>5 \mathrm{~km}$ ). The MWRA program also has data for mussels 
collected from several shoreline locations including the southwest portion of Cape Cod Bay near Sandwich, MA, Cape Ann in northern Massachusetts Bay, and recently from the Stover's Point in Maine (Figure 1). Collectively, the two programs characterize the major areas of Boston Harbor and Massachusetts Bay.

Six Mussel Watch stations, located in Massachusetts Bay, are used to characterize conditions in the northern and southern portions of the Bay and in the smaller embayments and harbors. The Mussel Watch program samples three locations within Boston Harbor: Dorchester Bay (BHDB), the northern Harbor near Deer Island (BHDI), and Hingham Bay (BHHB). In contrast the MWRA program characterizes the Inner Harbor $(\mathrm{IH})$ and the outer portions of the Harbor at the southern end of Deer Island at Deer island Light (DIL). The conditions of the offshore waters are characterized by one Mussel Watch station on Brewster Island (BHBI) and one MWRA outfall station (OSM) located approximately nine miles east of Deer Island in Massachusetts Bay and one in the center of Cape Cod Bay (CCB).

While the two monitoring programs use similar analytical methods, have similar goals of assessing bioaccumulation potential, and have been conducted over a comparable time period, the approaches differ. The Mussel Watch program relies on resident species sampled from intertidal shorelines; the MWRA program transplants mussels in cages at subtidal locations that are continuously submerged during the exposure period. Moreover, the Mussel Watch sites are selected with the intention of collecting samples that are not disproportionately influenced by a single contaminant source, thus integrate across 
sources to represent areas larger than those under the influence of a single source. As are result, the Mussel Watch locations were chosen to avoid the range of point sources (e.g. CSOs, industrial discharges, and sewage outfalls) known to affect the coastal environment. Lauenstein et al. (1997) provided detailed descriptions of each Mussel Watch sampling site and an electronic file of site locations accompanies the chemical data file that is available upon request from these authors or on the Internet at http://nsandt.noaa.gov. The MWRA program is designed to test site specific responses to actions take to reduce contaminant loading to the Harbor and Massachusetts Bay.

Together these independent programs provide an excellent opportunity to compare and contrast the approaches and respective results.

The MWRA program collects mussels for its caging program from resident populations documented to have low background contaminant concentrations. This provides MWRA with natural populations with contamination concentrations that ensure bioaccumulation at the transfer sites can be accurately assessed. The resident mussel source location for the MWRA mussels has changed through time due to inability to retrieve a sufficient number of mussels within the size range $(5.5$. to $6 \mathrm{~cm})$ specified by its sampling requirements and variability in the chemical concentrations of the mussels. The retrieved mussels were keep cool and held in for no more than two days before deployment per (ASTM 2001). The mussels were checked for viability before deployment and only closed specimens added to the cages. The survival rate of the mussels recovered after the 60-day deployments was consistently above $95 \%$. 
The MWRA mussel deployment sites were selected to determine the short-term accumulation of anthropogenic contaminants in mussel tissue, thus the cages are often located well above the sediment/water interface, and in the case of two locations (Deer Island Light and Offshore in Massachusetts Bay) are designed to test conditions within the Deer Island Treatment Plant effluent plume. Table 1 compares the characteristics of the sites discussed in this study.

A second difference between the programs is the timing of the mussel collection. Mussel Watch stations are sampled from late fall through spring as does GulfWatch, a program that has used resident Mytilus edulis to monitor contamination in the Gulf of Maine region since 1993. GulfWatch (http://www.gulfofmaine.org/gulfwatch/) is an international monitoring program organized and administered by the Gulf of Maine Council on the Marine Environment (GOMC) that tracks spatial and temporal trends of contaminants in populations of blue mussels around the Gulf of Maine (GOMC, 2003). In contrast to the Mussel Watch and GulfWatch programs, the MWRA program retrieves mussels in June after the organisms have spawned. This was specifically established as a data quality objective to reduce the potential sources of variability in the organisms. The animals are deployed for 60 days. Sixty days were selected to ensure the organisms had sufficient time to "equilibrate" with their surroundings and across the range of contaminants being monitored (Durell et al. 2006). Moreover, the 60-day deployment interval is longer than most laboratory bioaccumulation tests which typically run for 28 days. The 60 days is also consistent with ASTM (2001) guidance for deployment of caged mussels. 
The third difference between the programs is the relative location of the organisms to the sediment. The Mussel Watch program's resident populations are attached to the hard substrates of their natural habitat; the MWRA cages are deployed at mid depth of the water column (Table 1). Thus, the MWRA organisms likely exposed to and "sample" a smaller proportion of resuspend sediment than the Mussel Watch and GulfWatch programs. Hence, the MWRA data provide a perspective that is oriented towards the water column response rather than the sediment-water interface.

One of the key features of the programs is the comparability of the analytical methods. For example, chemical analyses for these programs are performed on composite samples (see materials and methods section). Also, because the MWRA analytical program adopted the Mussel Watch methods, there are a number of commonalities in the chemicals measured (Table 2). Those that are common and considered in this paper are total PAH, low molecular weight PAHs (LMWPAH), high molecular weight PAH (HMWPAH), total polychlorinated byphenols (tPCB), total DDT (tDDT), total chlordane (tChlordane), lindane, deildrin, mercury $(\mathrm{Hg})$, and lead $(\mathrm{Pb})$. Other chemicals (e.g., $\mathrm{Cu}$ in the Mussel Watch data set) are brought into the discussion to broaden the understanding of contaminant trends in this system.

\subsection{Materials and Methods}

The ability to compare the results of the programs requires that several assumptions be met. The first is that caged mussels "equilibrate" with surrounding water within the 60day deployment period. As noted above, common understanding among investigators is 
that 60 days is sufficient for these organisms to adjust to the exposure levels experienced at the deployment sites (ASTM, 2001; Axelman et al., 1999; Baussant et al., 2001; Durell et al. 2006; Neff and Burns, 1996; Peven et al. 1996; Prest et al., 1992; Salazar and Salazar, 1995). A second assumption is that analytical differences between the programs are minor.

The lipid content of the organisms and seasonality of exposure levels can also affect the concentrations of contaminants in bivalves (Capuzzo et al. 1986; Cain and Luoma 1985, 1990). This can be problematic for studies that attempt to compare the concentrations across the studies, although differences can be addressed through lipid normalization. The MWRA program normalized chemical contamination to the lipid content of the mussels through 1998. The normalization was dropped after the program examined the value of lipid normalization relative to its program goals and found lipid normalization did not substantially alter the trends when compared to lipid-normalized data (Mitchell et al. 1998). The MWRA program has also found the lipid content of mussels it deploys is consistently low and not highly variable (Lefkovitz et al. 2004). For example the average lipid content in the mussels analyzed in 2003 ranged from lower values at DIL (7.5 \pm $0.9 \%$ dry $)$ and $\mathrm{IH}(6.6 \pm 0.8 \%$ dry $)$ to higher but similar values measured CCB $(10.3 \pm$ $0.5 \%$ dry $), \mathrm{LNB}(10.1 \pm 0.5 \%$ dry $)$, and at four locations along the two kilometer MWRA outfall diffuser (OS-M1 (8.5 $\pm 1.3 \%$ dry), OS-M4 (9.1 $\pm 0.6 \%$ dry), and OS-M6 (8.9 \pm $0.9 \%$ dry)). The trend comparison among these independent programs is thus based on each program's reporting standards. 
The Mussel Watch Program collects organisms in the months of November through March with each site visited within 30 days of a prescribed date (O'Connor and Lauenstein 2006). From 1986 through 1991, six separate composite samples of 30 mussels each were collected at each Mussel Watch site. Three composite samples were homogenized for trace element analyses and three for trace organic analyses. Since 1992 only two composite samples have been collected; one for organic and one for trace element analysis. This is fewer than prior to this time and limits the robustness of the field replication, although the program has shown the variability among collected replicates is small. NOAA prefers specimens 5 to $8 \mathrm{~cm}$ in length $\left(\mathrm{O}^{\prime}\right.$ Connor and Lauenstein 2006). The mussels are not shucked in the field but scrubbed with a nylon or natural fiber brush to remove adhering detritus. When the mussels adhere to one another they are separated. The cleaned samples are packed in ice or dry ice and shipped to the analytical laboratory. Composite samples are prepared by homogenizing the soft parts of 30 mussels.

The MWRA program seeks mussel specimens that are 5.5 to $6.5 \mathrm{~cm}$ in length. The shell is cleaned and specimens shucked in a Class-100 clean room. Replicate composite samples are prepared by homogenizing the soft parts of the mussels. Depending on MWRA's site deployment requirements, four to eight composite samples per station are prepared, each containing 20 mussels. This provides very robust analytical replication. All soft tissue, including fluids, are placed into a clean glass jar and homogenized for analysis using a Titanium Tekmar "tissumizer" rinsed with methanol and de-ionized water prior to use. MWRA composite samples are split for organic and inorganic 
chemical analyses. For metals analyses, a 20-gram subsample is separated using a titanium or Teflon utensil and placed in a pre-cleaned four ounce plastic jar for storage. All composite splits were stored frozen prior to analysis.

\section{b. Sample processing}

Sample preparation procedures are also similar for these programs, although digestion procedures prior to elemental analysis varied to some extent among laboratories and years. For example, prior to 1990 the Mussel Watch analytical laboratory used concentrated nitric and perchloric acids in a Teflon digestion bomb in a conventional oven. Since 1991, samples have been digested in nitric acid only, and heating has been by microwave irradiation. The current Mussel Watch method involves sequential addition of nitric acid and hydrogen peroxide to Teflon bombs to achieve sample dissolution.

Sample extraction for organic chemical analysis was also similar among laboratories. In summary, after addition of internal standards and anhydrous sodium sulfate, the tissue was extracted three times with dichloromethane using a tissumizer. After concentration by solvent evaporation and exchange of dichloromethane with hexane, the tissue extract was fractionated by alumina:silica chromatography. The aromatic fraction eluted from the column with 1:1 pentane:dichloromethane was further purified by removing lipids through chromatography on a Sephadex column. Since 1988, this purification has been accomplished via gel permeation chromatography (GPC) and a high performance liquid chromatography (HPLC) procedure developed by Krahn et al. (1988). The Mussel Watch organic sample extraction since 2000 was similar to that of previous years but 
Hydromatrix ${ }^{\circledR}$ is used to dry tissue samples and dichloromethane is the only solvent used in Accelerated Solvent Extractor cells. Extracts are purified using alumina/silica gel chromatography followed by HPLC. The MWRA samples were fractionated using HPLC and the post-HPLC extract concentrated under nitrogen with a recovery internal standard (RIS) added. Dry weight determinations were performed by oven drying a portion of each composite sample. Extracts were split for PCB/Pesticide and PAH analyses with half remaining in DCM for PAH analysis and the other half solvent-exchanged with isooctane for PCB and pesticide analysis.

\section{c. Analytical}

From 1986 through 1994 the Mussel Watch organic contaminants were analyzed by scientists from the Battelle Laboratories in Duxbury, MA and Sequim, WA (O'Connor and Lauenstein, 2006). For 1994 through 1999 the samples were analyzed by the Geochemical and Environmental Research Group or the Department of Oceanography at Texas A\&M University in College Station, TX. Since 2000, all samples have been analyzed by TDI-Brooks in College Station, TX. Detailed descriptions of sampling and analytical protocols are available (Lauenstein \& Cantillo, 1993a-d and 1998). Mussels collected under the MWRA program were analyzed by InchCape Testing in 1991 and 1992. From 1993 through 1994 and again from 1998 through 2003, the Battelle Laboratories in Duxbury, MA and Sequim, WA conducted the MWRA mussel analysis program. From 1995 through 1998 the samples were analyzed by Arthur D. Little, using Mussel Watch methods. 
The MWRA analytical procedures are similar to the Mussel Watch methods and are summarized here. PAHs were identified using electron impact gas chromatography/mass spectrometry (GC/MS). Target compounds were separated using gas chromatograph and measured using a mass selective detector operated in the selective ion monitoring (SIM). Pesticides and PCB congeners were analyzed using gas chromatography/electron capture detection (GC/ECD) including a second column for confirmation. Concentrations for all target chemicals were determined by the method of internal standards, using SISs for quantification. All PAH, PCB and pesticide results are reported in ng/g dry wt.

For the Mussel Watch program, all laboratories, in all years, have used cold vapor atomic absorption for the analysis of Hg. TDI-Brooks International, Inc who has been performing the analyses since 2000 uses a modified version of EPA method 245.6. At Battelle, analyses for As, $\mathrm{Cu}, \mathrm{Se}$, and $\mathrm{Zn}$ have been made by $\mathrm{X}$-ray fluorescence and those for $\mathrm{Cd}, \mathrm{Ni}$, and $\mathrm{Pb}$ by graphite furnace atomic absorption (GFAA) after samples are digested. Beginning in 1992, inductivelycoupled plasma with mass spectroscopy detection (ICP/MS) was used for $\mathrm{Cd}, \mathrm{Cr}, \mathrm{Ni}$, and $\mathrm{Pb}$. The analytical instruments used by SAIC and TAMU were GFAA for $\mathrm{As}, \mathrm{Cd}, \mathrm{Ni}, \mathrm{Pb}$, and $\mathrm{Se}$; flame atomic absorption (FAA) for $\mathrm{Zn}$; and both GFAA and FAA for $\mathrm{Cu}$, depending on the concentration present. Arsenic and Se have been analyzed by atomic fluorescence spectrometry since 2000. Arsenic has also been analyzed by ICP-optical emission spectrometry (ICP/OEP). ICP/OEP is also used to determine $\mathrm{Cu}, \mathrm{Ni}$ and $\mathrm{Zn}$ while ICP/MS is used for $\mathrm{Cd}, \mathrm{Ni}$ and $\mathrm{Pb}$.

\section{d. Inter-laboratory comparisons}


The laboratories providing Mussel Watch and the MWRA data each participated annually in an inter-calibration exercise where common samples are analyzed by these laboratories, by other laboratories, and by a lead laboratory for the exercise. The primary laboratory for trace element inter-calibrations has been the National Research Council of Canada and the lead laboratory for trace organic analysis has been the National Institute of Standards and Technology. Results from the intercalibration exercises are published (Schantz, Parris \& Wise, 2000; Willie, 2000). Typically, the laboratories perform well relative to each other and the lead laboratory. This, and the commonality among the laboratories conducting laboratory analysis for these two studies, provides substantial confidence that the data generated by the two programs are highly comparable at the analytical level. Thus, the ability to compare results and trends is assumed to be high based on the analytical comparisons.

\section{e. Compound class total concentration}

Chemical classes such as PAHs, PCBs, chlordane and DDT include several congeners or chemical compounds. To estimate the total concentration of these chemical classes in the mussels, both the Mussel Watch program and MWRA program sum the concentrations of selected compounds. The PAH, DDT, and Chlordane compounds used to estimate the total concentration of these compound classes are the same for the two programs as identified in Table 2. The tPAH estimates are based on the 24 PAH compounds used in the Mussel Watch program, although more PAH compounds are quantified by the analytical laboratories. LMWPAH are defined as the sum of the 12 low molecular weight compounds shown in Table 2. HMWPAH is defined as the sum of 13 high molecular 
weight compounds shown in Table 2. In contrast, the method of estimating tPCB is different between the two programs. The Mussel Watch tPCB multiplies the sum of the reported PCB congeners by two to estimate $\mathrm{ACB}$, whereas MWRA only reports the sum of the congeners detected. The factor of two applied by the Mussel Watch program makes direct comparison of total concentrations problematic. Thus for comparative purposes, the graphical representations of Mussel Watch tPCB in the results section of the paper have been divided by two. The methodological difference does not affect trend statistics as the two data sets are treated independently in this paper.

\section{f. Trend Statistics}

A trend is defined as a statistically significant correlation between a contaminant concentration and year. In this paper, Spearman rank correlations ${ }^{1}$ based on rankings of concentrations are used, because, unlike parametric correlations, they are free of assumptions about concentrations at a site being normally distributed with a common variance among sites (O’Connor and Lauenstein, 2006). Moreover, because the trend analysis is based on ranks rather than absolute concentrations, correlations are unaffected by particularly large between-year differences. Such differences, if they appear near the beginning or end of a temporal sequence, can force a parametric correlation to appear significant when, there is no consistent trend among the data as a whole. The NOAA

\footnotetext{
1 “In statistics, Spearman's rank correlation coefficient, named after Charles Spearman and often denoted by the Greek letter $\rho$ (rho) or as $r_{s}$, is a non-parametric measure of correlation - that is, it assesses how well an arbitrary monotonic function could describe the relationship between two variables, without making any assumptions about the frequency distribution of the variables"(Wikipedia, the free encyclopedia ).
} 
calculations were performed with the SYSTAT package (SYSTAT, 2004); the MWRA calculations were performed using SAS statistical software (SAS 2005) ${ }^{2}$. For sites with analytical or field replicates the site mean was used for the trend analysis. Trends over time were also characterized in terms of slope using "sen estimates", which are nonparametric and thus are robust to outliers and require no distributional assumptions. The non-parametric Sen-Adichie tests were performed to asses whether the rates were inconsistent for the programs over time. Evaluations for comparability in measurements for co-located sites at Deer Island were made using Spearman rank correlations.

\section{g. Lowest detected concentrations and treatment of non-detected concentrations}

Analytical results from both programs showing no usable signal were treated as zero (0) concentrations. This can complicate trend detection because zeros will always be the lowest possible concentration, while non-zeros in other years could possibly indicate greater analytical sensitivity rather than higher concentrations. For the trace elements and the aggregated organic compounds for which trends have been calculated, zeros were infrequent and do not affect the trend analysis.

\subsection{Results}

The data from the two programs provide an exceptional ability to examine both spatial and temporal trends within Boston Harbor and Massachusetts Bay over decadal time scales. Chlordane provides an excellent chemical to demonstrate the general trends observed in Boston Harbor since the Spearman correlation is significant at the $95^{\text {th }}$

\footnotetext{
${ }^{2}$ The choice of statistical packages is a function of those available to statisticians who performed the statistical analysis.
} 
percentile $(p<0.05)$ for each of the stations sampled (Table 3$)$. As demonstrated in Figure 2, Boston Harbor was characterized by high and variable tChlordane concentrations in the late 1980s and early 1990s. During this period, tChlordane concentrations in Boston Harbor ranged from 20 to over 80 ppb (dry wt) depending on location and program. In the mid to late 1990s, the concentrations became less variable and generally lower, ranging between 20 and $30 \mathrm{ppb}$ (dry wt.). Notable in these data is the broad similarity of the reported concentration data obtained within the same year by the two programs from stations within the harbor. For example, between 1993 and 1998 tChlordane concentrations in the mussels from inner Boston Harbor (IH) and the two Deer Island locations (DIL and BHDI)) were between 20 and 30 ppb. After 1998 and continuing through 2003, spatial differences appear to develop with lower concentrations at the DIL site relative to the above two sites. By 2001, tChlodane concentrations at the two Deer Island locations and Brewster Island were less than $10 \mathrm{ppb}$ and approaching the temporally consistent, low concentrations ( $\sim 4 \mathrm{ppb})$ measured in Cape Cod Bay (CCB) by MWRA. Concentrations in the MWRA Inner Harbor and Mussel Watch Dorchester Bay stations also decreased but remained above $10 \mathrm{ppb}$ after 2001. These concentrations were also substantially lower than measured prior to 2000, when MWRA outfall was relocated into Massachusetts Bay.

The system's response to the outfall relocation in 2000 is evident in the mussels if data from the MWRA outfall location (OSM) is compared to these stations. Except for the Inner Harbor and for the DIL pre-outfall diversion period, long-term decreasing trends in tChlordane and lower inter-annual variability as sewage treatment process changed from 
primary to secondary are evident. Also noted was a clear increase at the outfall site in Massachusetts Bay after the effluent relocation.

Concentration changes over time at the DIL and BHDI locations $(\sim 3 \mathrm{~km}$ apart $)$ are directly compared in the lower right panel of Figure 2. The 1:1 line in this figure shows similar values late in the period compared (lowest values in the plot which are after 2000) but clearly higher tChlordane at the BHDI locations relative to DIL for most of the sampling dates that could be paired (1991, 1992, 1993, 1995, 1997, 2001, and 2003).

In contrast to the tChlordane, temporal trends $\mathrm{PCB}$ concentrations (Figure 3) were less evident, primarily due to large variability in the reported concentrations before 1994 and relatively weak downward changes in concentrations over time. The only station with a clear tPCB trend is the Mussel Watch Dorchester Bay site, especially after 1990, although the Inner Harbor and Brewster sites trend slightly downward and DIL does not appear to trend over this 13 year data set. The PCB data also shows greater spatial variability than observed in the tChlordane data. As observed in the tChlodane data, the MWRA Cape Cod Bay and MWRA ocean outfall sites had the lowest tPCB concentrations ( $<50 \mathrm{ng} / \mathrm{g}$ ). Concentrations at the MWRA Deer Island and Mussel Watch Brewster Island sites were elevated relative the offshore waters $(\sim 250 \mathrm{ng} / \mathrm{g})$, while the Mussel Watch Dorchester Bay and Deer Island sites plus MWRA Inner Harbor stations had very high ( $\sim 300$ to $500 \mathrm{ng} / \mathrm{g}$ ), and similar concentrations throughout the combined period compared. 
Concentration changes over time at the DIL and BHDI locations are directly compared in the lower right panel of Figure 3. The 1:1 line in this figure shows several similar values except for three Mussel Watch data points $(1992,1995,1997)$ that are well above the MWRA data.

Total DDT in Boston Harbor/Massachusetts Bay is characterized by highly variable year to year concentrations in the late 1980s and early 1990s (Figure 4). In the early 1990s, when both programs sampled the harbor, tDDT concentrations appeared to decrease from the Inner Harbor to offshore. Each site sampled within Boston Harbor appears to have decreasing concentrations throughout the monitoring period. Spatially, total DDT concentrations in the Inner Harbor and Dorchester Bay remained well above the MWRA Deer Island site, and especially the Brewster Island, Cape Cod Bay, and Outfall sites, especially prior to 1998 . After 1998, the Brewster Island mussel data generally reflected concentrations and relative changes observed in the MWRA and Mussel Watch Deer Island sites with each site showing a decreasing trend from the mid 1990s. In contrast, the Inner Harbor and Dorchester Bay data remained higher throughout the period, although the data from each site tends to decrease, especially after 1995.

The Mussel Watch and MWRA Deer Island stations show generally similar DDT concentrations in the mid 1990s (ranging from 40 to $80 \mathrm{ppb}$ ). After 2000, the concentrations at the two Deer Island locations were lower (20 to $40 \mathrm{ppb}$ ) than in the late 1990's and more similar between the sites. Direct comparison of concentration changes over time at the DIL and BHDI locations (lower right panel of Figure 3) shows the DIL 
data were generally equal to or lower than measured at BHDI. The years with similar concentrations were from late in the monitoring period.

Total PAH has the largest concentration range across the system (50 to $6000 \mathrm{ppb}$ ) and through time (Figure 5). This large range is similar to those observed in other systems. The highest concentrations over the period of record were reported prior to 1995. After 1995, concentrations were consistently less than $100 \mathrm{ppb}$ at the Massachusetts Bay stations (OSM and CCB) and approximately $2000 \mathrm{ppb}$ in the Inner Harbor, a 20 fold difference. A temporal trend was not clearly evident in the Inner Harbor data although both the DIL and BHDI location had decreasing trends. Similar to tChlordane, but unlike the other chemicals, tPAH concentrations at the MWRA outfall site (OSM) increase slightly in the early 2000s, in response to the relocation of the outfall and the proximity of the caged mussels to the effluent plume after diversion. The observed increases in tChlordane and tPAH are consistent with changes expected based on theoretical bioaccumulation equations (Pruell et al. 1986, Bergen et al. 1993, Neff and Burns, 1996) and applied to the MWRA data by Hunt et al. (2002a).

The Mussel Watch and MWRA Deer Island stations clearly showed differences in concentration through out the period monitored. The maximum concentrations found at DIL after 1992 were typical of the concentrations found at BHDI throughout the period being compared. These are directly compared in the lower right panel of Figure 3. Relative to the 1:1 line in this figure the DIL data were lower than measured at BHDI. 
The concentrations at the two Deer Island locations became more similar later in the period of record.

As observed in the organic chemical data, mercury concentrations in the mussels in the late 1980s and early 1990s were relatively high and variable (Figure 6) with concentrations typically over $0.2 \mathrm{ppm}$. Concentrations after the mid 1990s were typically under $0.2 \mathrm{ppm}$. After the mid 1990s the spatial variability in the mercury data appeared to decrease with the highest concentrations measured at the MWRA Inner Harbor site, and surprisingly at the Mussel Watch Brewster Island site. Other than at this station, recent spatial and inter-annual variability tended to be small with concentrations relatively similar at outer Harbor and Massachusetts Bay locations (between 0.1 and $0.2 \mathrm{ppb}$ ). Consistent harbor wide trends were not evident in the mercury data after the mid 1990s.

\subsection{Discussion}

O’Connor and Lauenstein (2006) updated a previously published (O'Connor, 1996) national and regional trend evaluation with data generated through 2003 and report that chemicals "with concentrations on a decreasing trend in 1993 remain on that trend". Furthermore, they indicate "concentrations of two chemicals, lindane (gamma isomer of hexachlorocyclohexane) and high molecular weight PAHs, not on a decrease through 1993 are now showing such a trend", that "no chemical concentrations are increasing on a national scale", and that "cadmium remains the only metal showing a national trend". Moreover, they find the data obtained since 1996 "reveal some trends in concentrations of metals within geographic groups of sites". More recently Kimbrough et al. (2008) 
summarize the Mussel Watch data and tends through 2005 and reach conclusions similar to those of O'Connor and Lauenstein (2006).

The supporting data from O'Connor and Lauenstein (2006) for the Massachusetts Bay Mussel Watch sites were reviewed for this paper. The review found that many chemicals for the Massachusetts Bay Mussel Watch sites had significant decreasing trends at the 95\% confidence level or 90\% confidence level. However, O'Connor and Lauenstein (2006) indicate arsenic, nickel, and selenium exhibit significant increasing trends at some Boston Harbor/Massachusetts Bay sites. The most significant upward trend (at the $95 \%$ confidence level) was for arsenic in Nahant, Dorchester Bay, and Hingham Bay, and selenium in Hingham Bay and at Brewster Island. Several of the Mussel Watch sites exhibit decreasing trends for three or more contaminants (Table 3). The Mussel Watch Deer Island site had the largest number of chemicals (8) with statistically significant decreasing trends; the other Mussel Watch sites discussed in this paper had between one and six chemicals with significant decreasing trends. The Mussel Watch Nahant site had the fewest number of significant decreasing trends (2) plus one chemical (arsenic) with a significant upward trend (O'Connor and Lauenstein, 2006). Two chemicals did not show trends at any site (high molecular weight PAHs and cadmium). Among the Mussel Watch sites, only Deer Island had a significant trend for tPAH (decreasing). In contrast, tChlordane a decreasing trend at the Mussel Watch sites in the Boston Harbor/Massachusetts Bay region was found (Table 3), consistent with the national trend for this chemical class. The tDieldrin and tDDT concentrations decreased at five Mussel Watch Sites but none of the MWRA sites; however, both chemicals trended downward at 
only four of these Mussel Watch sites. The only sites with significant tPCB trends were North River in Massachusetts Bay and Clarks Island in Duxbury Bay. Both of these sites are south of Boston Harbor. Overall, the Mussel Watch data generally show decreasing trends or no trends for any chemicals. This suggests improved environmental quality in Boston Harbor and Massachusetts Bay over the past 20 years with respect to chemical contamination.

To compare trends in the data from the two programs, individual MWRA site data was subjected to the same statistical tests used by O'Connor and Lauenstein (2006). The MWRA caged mussel data from 1994 through 2003 had statistically significant decreasing trends (at least $90 \%$ significance level; $p<0.1$ ) for one to five chemicals depending on the station (Table 3). Within the MWRA data set, the Deer Island site had the greatest number of downward trends ( 5 of 10 chemicals). In contrast, the MWRA Inner Harbor site did not have any significantly decreasing trends. This may be due to exposure to sources other than the outfall and suggest a slower recovery rate from the input of these chemicals in this region of the harbor. No trends were detected in tDDT, tDieldrin, tPCB or $\mathrm{Hg}$ in the MWRA data. Only tChlordane decreased significantly in CCB.

In contrast to these generally decreasing trends, significant upward trends (95\% confidence level) in tPAH, tChlordane and lindane were found at the MWRA outfall site. A second set of caged mussels deployed approximately $1 \mathrm{~km}$ south of the MWRA 
diffuser in Massachusetts Bay at a navigation marker known as the B-Buoy (LNB) did not show significant trends.

Increasing trends for some chemicals at MWRA's outfall site were expected after diversion in 2000 based on the experimental design for this MWRA site. The design placed the caged mussels directly in the effluent plume which was estimated to be diluted 70:1 (Hunt et al. 2002b). Prior to diversion, the area did not receive direct input of effluent, thus displayed low bioaccumulation levels. On first consideration, the slightly higher concentrations and increasing trend was presumed to result from the higher contaminant exposure levels as a result of the discharge. However, comparisons of these data to the chemical concentrations in pre-deployment mussels suggest the outfall was not solely responsible for the upward trends of several of the contaminants. For example, pre-deployment data suggest that the apparent increase in mercury concentrations are more likely related to the initial concentration in the mussels used in the study as the mercury data at OSM closely reflects the increasing trend of chemicals in pre-deployment mussels after 1999 (Figure 7) as noted in Lefkovitz et al., (2006, 2004). Note the postdiversion data from the LNB location also mirrors the pre-deployment mussel concentrations but were slightly lower than at the OSM site ( 0.17 vs 0.14 and 0.13 vs 0.11 in 2002 and 2003, respectively). As a result, the mercury at this station does not show a statistically significant trend. The small difference in contaminant concentrations at the two sites, which are 1,000 m apart, is consistent with greater effluent dilution at the LNB location ( 1000 vs 70). In contrast, the mercury in the mussels deployed in Cape Cod Bay appeared to decrease relative to the pre-deployment concentrations (Figure 7). 
Similar observations can be made for lead, but not tDDT, tChlordane, tPCB and tPAH. Note the statistical analysis suggested there is no trend for lead at OSM and a decreasing trend at LNB, consistent with the variability in data and influence of the pre-deployment lead concentration in the mussels. By comparison, while the decreasing trends for tDDT and $\mathrm{PCB}$ at OSM and LNB were significant, there are clear inflection points in these parameters in 2000, with concentrations decreasing before diversion and increasing after diversion. Noteworthy in the organic chemical data are the mussel tissue concentration increases since 2000 that do not mirror the pre-deployment concentrations. The data for tPAH and tChlordane suggest the statistical trends better reflect outfall related effects since the pre-deployment concentrations of these chemicals were low relative to the post -deployment concentrations and more uniform. This creates confidence that the statistical analysis reflects true trends in the tissue chemistry data rather than changes in the concentrations of contaminants in the pre-deployment mussels, as suggested by the lead and mercury data.

The MWRA and Mussel Watch data sets also allowed for a limited comparison of the trends observed between the two programs at nearby sites. For this comparison sen estimates for the trends were produced (Table 4) for the mercury, PAH, PCB, tChlordane, and DDT data from the co-located Deer Island locations. Results indicate that all measurements (except PCB) show a decreasing trend over time for both programs. This finding is also true when the NOAA data is subsetted to 1991-2003. In order to assess whether these trends are dissimilar, Sen-Adichie test results are presented in Table 4. 
These results indicate that only tChlordane rates for NOAA and MWRA are not parallel when all available data is considered. However, when the NOAA data is restricted to 1991-2003, results indicate that while tChlordine rates are consistent, that Mercury rates are not.

The trends observed in these two independent data sets from Boston Harbor complement each other and enable comparison of the results of the MWRA facility improvements and reduction in chemical loading over an eighteen year time frame. Taylor (2005) has defined four major intervention periods for Boston Harbor that correspond with the major steps resulting in chemical load reductions from MWRA facility improvements. They are (1) Pre-period A, including data from 1991 to 1994 just after discharge of sewage sludge was stopped, (2) Period A, including data from 1995 to 1998 when improvements in primary treatment were completed, (3) Period B, including data from 1999 and 2000 when secondary treatment was implemented, and (4) Period C, including data from 2001 to 2005 after sewage discharge was stopped in Boston Harbor. For this paper, Pre-period A is extended back to 1986 where the NOAA Mussel Watch Program provides relevant data for trend and response assessment. These interventions provide clear points against which temporal changes in Boston Harbor can be evaluated.

Both data sets show high and variable chemical concentrations in the mussels collected from Boston Harbor through the period of sludge discharge and poorly treated effluent (1986 through 1994). Both the MWRA and Mussel Watch program record decreasing spatial and temporal variability. Variability in the early 1990's may have affected the 
ability to detect differences in chemicals between caged and resident mussels, seasonal variability not withstanding. A decreasing trend in chemical concentrations in mussels became evident after sludge discharge ended (1991) and advanced primary treatment was implemented (1995). Additional decreases in the spatial and temporal variability and chemical concentrations in Boston Harbor continued as secondary treatment was brought on line (1998 through 2000) and after the outfall was moved offshore (2000). Moreover, the concentrations of chemicals in the outer Harbor and offshore Massachusetts Bay appear to converge (with the exception of a few chemicals) in the early 2000 s. Hence, the two data sets complement each other and consistently document decreasing trends in the Harbor and Bay.

One additional contrast that is afforded by these two data sets is a comparison of these data to those generated by the GulfWatch program. Samples are collected each fall from 56 sites on a rotating basis and analyzed for trace metals, PCBs, PAHs, and pesticides. Analytical methods are similar to the Mussel Watch and MWRA programs. Sampling sites within Massachusetts include stations in the Inner Harbor, outer Boston Harbor (near Long Island) and Sandwich (one of five benchmark sites sampled annually) and mussel tissue chemistry measured during the GulfWatch program are comparable to those measured in mussels deployed as part of the MWRA monitoring program (e.g., within a factor of 1.8 for organic contaminants, a factor of seven for mercury, and factor of four for lead (Table 6). The large differences in these latter parameters affect the ability to detect differences among these programs. These data support the spatial 
findings discussed previously in that contaminants in mussels are generally highest in the Inner Harbor and decrease with distance from the Inner Harbor.

This comparison has added value in that questions often arise regarding the ability of caged mussels and resident mussel populations to represent contaminant trends. The MWRA, Mussel Watch, and GulfWatch data support the concept that either approach can effectively reveal trends in environmental chemical contamination, especially when consistently applied through time. There are, however, differences beyond those considered previously that are worth further discussion. Examination of the data in this paper reveal some unexpected differences at the sites located in the outer reaches of the Harbor and western Massachusetts Bay. For example, the chemical concentrations from the Mussel Watch Deer Island site are generally higher than at the MWRA Deer Island site data until after the outfall relocation in 2000 (see for example Figure 3 tPCB). While this difference could be due to seasonal factors, it may also represent a difference in the mussel deployment methodology (mid water caged mussel versus intertidal resident populations) or reflect transport and concentration of effluent particles in the Mussel Watch site by tidal circulation. The seasonal factor is a less attractive rationale as the differences would be expected to continue after the outfall was transferred offshore. In contrast, physical factors such as tidal circulation and sediment transport could explain the difference. The tidal circulation in this area is such that the effluent could have been focused in this area on an in coming tide or the mussels exposed to resuspended surface sediment and particles that reflect the outfall as a long-term contaminate source. The convergence of the chemical concentrations in the mussels from the two sites after the 
outfall relocation suggests either or both of these later mechanisms may have been operating (i.e., the above argument regarding differences being caused by proximity to sediment versus water column). However, these are speculation that would require fine scale studies to sort out the causes.

A final consideration is how these programs complement each other. This is particularly relevant given the trends identified in the different programs. The NOAA Mussel Watch data cover a much longer assessment period but is less frequently sampled when compared the MWRA Program. However, the MWRA's shorter assessment period was sampled annually which provides greater resolution of the time series. Regardless of design, the data from each program independently identify statistically significant trends over this 20 year record. The "starting point" for each program reflects conditions in the harbor which were apparently driven by the high chemical loads in the 1980s and early 1990's. Presumably, these loads were driven by sludge discharge that was stopped in 1991. Once these chemical loads were better managed and loads decreased, both programs were able to detect improvements to Boston Harbor water quality with the slope of the trend differing slightly for selected chemicals (e.g., chlordane and mercury) at the two Deer Island sites after 1991. Since the MWRA program was required by its NPDES permit to provide annual data, that program appeared to provided a more powerful means of assessing recent trends given the generally lower concentrations and moderate variability in the data found after 1998. However, the statistical demonstration of trend comparability after 1991 at the two Deer Island locations indicted a high degree of comparability. Given the methods and general data comparability, the MWRA 
program filled in the data record for years that the Mussel Watch program did not sample and confirmed the longer-term trends detected by the Mussel Watch program, increasing the confidence in that program's findings.

One aspect of the caged mussel approach that bears discussion is its ability to detect changes in bioaccumulation when exposure conditions are not greatly different than the environment from which the mussels were taken and chemical gradients. This stems from the need to factor in variability and trends in the contaminant concentrations in the source mussels for the trend assessment. The data suggest that caged mussel deployments may be better monitoring tools when strong chemical gradients are present. Caged mussels also provide great flexibility in assessing specific sources of contaminants due to the ability to place the cages where needed in three dimensional space and in time, as demonstrated recently for offshore oil platform monitoring (Durell et al. 2006).

\subsection{Conclusions}

The data evaluated in this paper clearly demonstrate the complementary nature of resident and caged (transplanted) mussels for contaminant trend assessment. The data sets each describe long-term trends in chemical contamination in Boston Harbor even though the basic approaches and sampling frequency differ. Moreover, each approach has strengths that are important for both short- and long-term assessment and monitoring. The caged mussel approach is particularly useful when natural bivalve populations are not available and has the flexibility to evaluate bioaccumulation in hard-to-reach areas, such near outfalls, or in different strata in the water column. Although not detailed in this paper, the caged approach is also adaptable to transport studies through the ability to 
locate the cages along suspected or known contaminant transport paths. Such flexibility is essential for small scale or site specific studies. In contrast, resident mussels have the advantage of integrating exposure and bioaccumulation over broader areas (e.g., tidal range), over seasonal and biological cycles, and integrating exposure. Together these monitoring tools provide powerful means of ensuring environment quality is maintained.

These results also consistently indicate that contaminants in mussels in Boston Harbor are highest in the Inner Harbor and that concentrations decrease towards Massachusetts Bay. Moreover, the mussels in the 60-day caged deployments in Boston Harbor appear to have reached a steady state with the surrounding water column and provide contaminant data that are reasonably comparable to those of nearby resident mussel populations in spite of potential differences in season collected and biological conditions (e.g. lipid content). Moreover, these data sets each show long-term, statistically significant decreasing contaminants trends in Boston Harbor that can be linked to the decisions and investments made to improve the water quality of Boston Harbor. Together the concentration trends demonstrate wide scale improvements to the quality of Boston Harbor.

The power of these approaches lies in the ability to obtained repeated measures of environmental quality even when water column exposure data is missing. However, there are perhaps two areas where bioaccumulation monitoring and assessment using mussels can be improved. One is better information on the exposure field to improve the assessment of water quality using bioaccumulation data; the second is how mussels located in intertidal areas as near sediments differ from those suspended in the water 
column above the sediments. Do they tell the same story or can the differences be used to further our understanding of factors affecting bioaccumulation and environmental quality monitoring?

\section{Acknowledgements}

The field scientists from Battelle, NOAA, and GulfWatch are thanked for their conduct of the caged mussels and mussel collection surveys of Boston Harbor and Massachusetts and Cape Cod Bays. Laboratory scientists from Battelle and MWRA are thanked for their conduct of the chemical testing of the mussels sampled under the MWRA Harbor and Outfall Monitoring program. Tom O'Connor graciously provided the Mussel Watch data used in O'Connor and Lauenstein (2006) and commented on an early draft of the paper. Comments on the manuscript from Michael Salazar were extremely helpful in clarifying the relevance and importance of this comparison. Elizabeth Slone's help in addressing statistical concerns raised by the peer review are gratefully acknowledged.

\section{References}

ASTM. 2001. Standard Guide for Conducting In-situ Field Bioassays With Marine, Estuarine, and Freshwater Bivalves ASTM E2122, ASTM, 100 Barr Harbor Drive, PO Box C700,West Conshohocken, PA 19428-2959, United States 30p.

Axelman, J., Næs, K., Na“ f, C., Bromans, D., 1999. Accumulation of polycyclic aromatic hydrocarbons in semipermeable membrane devices and caged mussels (Mytilus 
edulis) in relation to water column phase distribution. Environ. Toxicol. Chem. 18, 24542461.

Baussant, T., Sanni, S., Jonsson, G., Skadsheim, A., Børseth, J.F., 2001. Bioaccumulation of polycyclic aromatic hydrocarbons: 1 . bioconcentration of two marine species and in semi-permeable membrane devices during chronic exposure to dispersed crude oil. Environ. Toxicol. Chem. 20, 1175-1184.

Bergen, B.J., W.G. Nelson and R.J. Pruell. 1993. Bioaccumulation of PCB congeners by blue mussels (Mytilus edulis) deployed in New Bedford Harbor, Massachusetts. Environ. Sci. Technol. 12:1671-1681.

Bothner, M.H., M.R. Buchholtz ten Brink, and E.T. Manheim. 1998. Metal concentrations in surface sediments of Boston Harbor-changes with time. Marine Environmental Research, 45(2), 127-155.

Bothner, M.H., and Butman, Bradford (eds.), 2007, Processes influencing the transport and fate of contaminated sediments in the coastal ocean-Boston Harbor and Massachusetts Bay: U.S. Geological Survey Circular 1302, 89 p.

Cain, D. J., and Luoma, S. N. 1985. Copper and Silver Accumulation in Transplanted and Resident Clams (Macoma balthica) in South San Francisco Bay. Mar. Environ. Res. Vol 15, pp. 115-135. 
Cain, D.J. and Luoma, S.N. 1990. Influence of seasonal growth, age and environmental exposure on $\mathrm{Cu}$ and $\mathrm{Ag}$ in a bivalve indicator, Macoma balthica, in San Francisco Bay. Mar. Ecol. Prog. Ser. 60 (1990), pp. 45-55.

Capuzzo, J. M., Farrington, J. W., Rantamaki, P., Clifford, C. H., Lancaster, B. A., Leavitt, D. F., and Jia, X., 1989. The Relationship Between Lipid Composition and Seasonal Differences in the Distribution of PCBs in Mytilus edulis L.," Mar. Environ. Res., Vol 28, pp. 259-264.

Durell, G.S., Roe Utvik, T.I., S. Johnsen, T. Frost, and J. Neff. 2006. Oil well produced water discharges to the North Sea. Part I: comparison of deployed mussels (Mytilus edulis), semi-permeable membrane devices, and the DREAM model predictions to estimate the dispersion of polycyclic aromatic hydrocarbons. Marine Environmental Research, 62, 194-223.

GOMC. 2003. Gulfwatch: Monitoring Chemical Contaminants in Gulf of Maine Coastal Waters. Available online:

http://www.gulfofmaine.org/council/publications/gulfwatchfactsheet.pdf.

Hollander, M. and D.A. Wolfe. 1999. Nonparametric Statistical Methods, Second Edition. John Wiley \& Sons, New York.

Hunt, C.D., S. Abramson, L.F. Lefkovitz, J. Neff, G. Durell, K.E. Keay, and M.P. Hall. 2002a. Evaluation of 2001 mussel tissue contaminant threshold exceedance. Boston: 
Massachusetts Water Resources Authority, Report ENQUAD 2002-05, 48. Available online: http://www.mwra.state.ma.us/harbor/enquad/trlist.html

Hunt, C.D., A.D. Mansfield, P.J.W. Roberts, W.R. Geyer, C.S. Albro, W.S. Steinhauer, and M.J. Mickelson. 2002b. Final Report: Massachusetts Water Resources Authority outfall effluent dilution: July 2001. Boston: Massachusetts Water Resources Authority, Report ENQUAD 2002-07, 77. Available online:

http://www.mwra.state.ma.us/harbor/enquad/trlist.html

Hunt, C.D., M.P. Hall, S. Pala, and D.T. Dahlen. 2005. A review and summary of contaminants in Boston Harbor and Massachusetts Bay: 1990 to 2005. Boston: Massachusetts Water Resources Authority, Report ENQUAD 2005-18, 136. Available online: http://www.mwra.state.ma.us/harbor/enquad/trlist.html

Hunt, C.D., D.T. Dahlen, S. Pala, M.P. Hall, and K.E. Keay,. 2006. Boston Harbor sediment quality responds to cleanup. Proceedings of OCEANS'06 MTS/IEEE - Boston, Boston, MA 18-21 September, 2006, 1-4244-0115-1/06 IEEE.

Kimbrough, K. L., W. E. Johnson, G. G. Lauenstein, J. D. Christensen and D. A. Apeti. 2008. An Assessment of Two Decades of Contaminant Monitoring in the Nation's Coastal Zone. Silver Spring, MD. NOAA Technical Memorandum NOS NCCOS 74. 105 pp. 
Krahn, M. M., C.A. Wigren, R.W. Pearce, L.K. Moore, R.G. Bogar, W.D. MacLeod, Jr., S-L. Chan, and D. W. Brown.1988. Standard analytical procedures for the NOAA national analytical facility, 1988: new HPLC cleanup and revised extraction procedures for organic contaminants. NOAA Technical Memorandum NMFS/NWC, 153, 52.

Lauenstein, G. G. and A. Y. Cantillo, ed.1993a. Sampling and analytical methods of the NS\&T program national benthic surveillance and mussel watch projects. Volume I. Overview and summary of methods. NOAA Technical Memorandum NOS ORCA, 71.

Lauenstein, G. G. and A. Y. Cantillo, ed. 1993b. Sampling and analytical methods of the NS\&T program national benthic surveillance and mussel watch projects. Volume II. Comprehensive descriptions of complementary measurements. NOAA Technical Memorandum NOS ORCA, 71.

Lauenstein, G. G. and A. Y. Cantillo, ed. 1993c. Sampling and analytical methods of the NS\&T program national benthic surveillance and mussel watch projects. Volume III. Comprehensive descriptions of elemental analytical methods. NOAA Technical Memorandum NOS ORCA, 71.

Lauenstein, G. G. and A. Y. Cantillo, ed. 1993d. Sampling and analytical methods of the NS\&T program national benthic surveillance and mussel watch projects. Volume IV. Comprehensive descriptions of trace organic analytical methods. NOAA Technical Memorandum NOS ORCA, 71. 
Lauenstein, G. G., A.Y. Cantillo, S. Kokkinakis, S. Frew, H.J. Jobling, and R.R. Fay. 1997. national status and trends program: mussel watch site descriptions through 1997. NOAA Technical Memorandum NOS ORCA, 112.

Lauenstein, G. G. and A.Y. Cantillo, ed. 1998. Sampling and analytical methods of the NS\&T program mussel watch project: 1993-1996 Update. NOAA Technical Memorandum NOS ORCA, 130.

Lefkovitz, L.F., C. Wisneski, M. Moore, and E. Schaub. 2004. 2003 annual fish and shellfish report. Boston: Massachusetts Water Resources Authority, Report ENQUAD 2004-11, 192. Available online: http://www.mwra.state.ma.us/harbor/enquad/trlist.html Lefkovitz, L.F., M.P. Hall, M. Moore, S. Pala, and C.D. Hunt. 2006. Fish and shellfish monitoring in Boston Harbor and Massachusetts Bay - 1992 through 2005. In press in Oceans, 2006.

Maciolek, N.J., R.J. Diaz, D.T. Dahlen, and I.P. Williams. 2006. 2004 Boston Harbor benthic monitoring report. Boston: Massachusetts Water Resources Authority, Report ENQUAD 2006-01, 113. Available online:

http://www.mwra.state.ma.us/harbor/enquad/trlist.html 
Mitchell DF, Sullivan KA, Moore MJ and Downey PC. 1998. 1997 annual fish and shellfish report. Boston: Massachusetts Water Resources Authority. Report 1998-12. 139 p. http://www.mwra.state.ma.us/harbor/enquad/pdf/1998-12.pdf

Neff, J.M., Burns, W.A., 1996. Estimation of polycyclic aromatic hydrocarbon concentrations in the water column based on tissue residues in mussels and salmon: an equilibrium partitioning approach. Environ. Toxicol. Chem. 15, 2240-2253.

Pruell, R.J., J.L. Lake, W.R. Davis, and J.G. Quinn. 1986. Uptake and depuration of organic contaminants by blue mussels, Mytilus edulis, exposed to environmentally contaminated sediment. Mar. Biol. 91:497- 505.

O'Connor, T. P. 1996. Trends in chemical concentrations in mussels and oysters collected along the U. S. coast from 1986 to 1993. Mar. Environ. Res., 41, 183-200.

O'Connor, T. P and G. G. Lauenstein. 2006. Trends in chemical concentrations in mussels and oysters collected along the U.S. coast: Update to 2003. Mar. Environ. Res., $62,261-285$.

Peven, C.S., A.D. Uhler, and F.J. Querzoli.1996. Caged mussels and semi-permeable membrane devices as indicators of organic contaminant uptake in Dorchester and Duxbury Bays, Massachusetts. Environ. Toxicol. Chem., 15, 144-149. 
Prest, H.F., Jarman, W.M., Burns, S.A., Weismu“ ller, T., Martin, M., Huckins, J.N., 1992. Passive water sampling via semi-permeable membrane devices (SPMD) in concert with bivalves in the Sacramento/San Joaquin River delta. Chemosphere 25, 811-823.

Rex, A.C., D. Wu, K. Coughlin, M.P. Hall, K.E. Keay, and D.I. Taylor. 2002. The state of Boston Harbor: mapping the Harbor's recovery. Boston: Massachusetts Water Resources Authority, Report ENQUAD 2002-09, 42. Available online: http://www.mwra.state.ma.us/harbor/enquad/trlist.html

Richardson, B.J., Zheng, G.J., Tse, E.S.C., De Luca-Abbott, S.B., Siu, S.Y.M., Lam, P.K.S., 2003. A comparison of polycyclic aromatic hydrocarbon and petroleum hydrocarbon uptake by mussels (Perna viridis) and semipermeable membrane devices (SPMDs) in Hong Kong coastal waters. Environ. Pollut. 122, 223-227.

Salazar, M.H., Salazar, S.M., 1995. In situ bioassays using transplanted mussels: 1. estimating chemical exposure and bioeffects with bioaccumulation and growth. In: Environmental Toxicology and Risk Assessment. In: Hughes, J.S., Biddinger, G.R., Mones, E. (Eds.), ASTM STP 1218, vol. 3. American Society for Testing and Materials, Philadelphia, pp. 216-241.

SAS. 2005. SAS Version 9.1.3. SAS Institute Inc. Cary, NC. 
Schantz, M. M., R.M. Parris, and S.A. Wise. 2000. NIST/NOAA NS\&T intercomparison exercise program for organic contaminants in the marine environment: description and results of 1999 organic intercomparison exercises. NOAA Technical Memorandum NOS NCCOS CCMA, 146.

SYSTAT. 2004. SYSTAT 11. SYSTAT Software Inc. Richmond, CA.

Taylor, D.I. 2005. Relationships between eutrophication-related water-quality, and changes to wastewater loadings to Boston Harbor. Boston: Massachusetts Water Resources Authority, Report ENQUAD 2005-21, 56. Available online: http://www.mwra.state.ma.us/harbor/enquad/trlist.html

Tucker, J., S. Kelsey, A. Giblin, and C. Hopkinson. 2006. 2005 annual benthic nutrient flux monitoring report. Boston: Massachusetts Water Resources Authority, Report ENQUAD 2006-17, 69. Available online:

http://www.mwra.state.ma.us/harbor/enquad/trlist.html

Werme, C. and C.D. Hunt. 2006. 2005 outfall monitoring overview. Boston: Massachusetts Water Resources Authority, Report ENQUAD 2006-18, 104. Available online: http://www.mwra.state.ma.us/harbor/enquad/trlist.html 
Willie, S. 2000. NOAA national status and trends program thirteenth round intercomparison exercise results for trace metals in marine sediments and biological tissues. NOAA Technical Memorandum NOS NCCOS CCMA, 142.

Zago, C., A.E. Giblin, and A. Bergamasco. 2001. Changes in the metal content of surficial sediments of Boston Harbor since the cessation of sludge discharge. Mar. Environ. Res., $51(5), 389-415$. 


\section{Tables}

Table 1: Station summary since the start of the NOAA sampling in 1986 (17 years); MWRA sampling began in 1991 (12 years).

Table 2. Chemicals measured under the Mussel Watch and MWRA monitoring programs.

Table 3. Table 3. Spearman rank correlation coefficient, trend direction, and significance level recorded in blue mussels sampled in the Boston Harbor and Massachusetts Bay region between 1986 and 2003 as collected by NOAA (from O'Connor and Lauenstein, 2006) and by MWRA.

Table 4. Table 4. Summary of sen trend estimates for trends in MWRA and Mussel Watch Deer Island emissions with related p-values $\left(^{*}=\right.$ significant at $5 \%$ level of significance).

Table 5. Comparison of the relationship between chemical measurements observed at the MWRA and Mussel Watch Deer Island stations. Correlations between measurements made during the same year are assessed through the Spearman correlation. Sen-Adichie assesses whether the trends in the data are not parallel over time and is calculated for all years as well as for 1991-2003.

Table 6. Comparison of Contaminants in Mussel Tissue from Other Areas. The means and standard deviations of the stations for 1998 GulfWatch stations are compared to the 199820081998. 
Table 1: Station summary since the start of the NOAA sampling in 1986 (17 years);

MWRA sampling began in 1991 (12 years).

\begin{tabular}{|c|c|c|c|c|}
\hline Program & Station & $\begin{array}{l}\text { Latitude/ } \\
\text { Longitude }\end{array}$ & $\begin{array}{l}\text { Sample } \\
\text { Depth }\end{array}$ & $\begin{array}{c}\text { Sampled } \\
\text { Years } \\
\text { (Number } \\
\text { Samples) }\end{array}$ \\
\hline \multirow[t]{4}{*}{ MWRA } & $\begin{array}{l}\text { Deer Island Light, Boston } \\
\text { Harbor }\end{array}$ & $\begin{array}{l}42^{\circ} 20.4^{\prime} \mathrm{N} \\
70^{\circ} 57.2^{\prime} \mathrm{W} \\
\end{array}$ & $5 \mathrm{~m}$ & $\begin{array}{c}1991-2003 \\
(\mathrm{n}=9)\end{array}$ \\
\hline & $\begin{array}{l}\text { Boston Inner Harbor, } \\
\text { Boston Harbor }\end{array}$ & $\begin{array}{l}42^{\circ} 21.5^{\prime} \mathrm{N} \\
71^{\circ} 02.9^{\prime} \mathrm{W}\end{array}$ & $7 \mathrm{~m}$ & $\begin{array}{c}1991-2003 \\
(\mathrm{n}=10)\end{array}$ \\
\hline & $\begin{array}{l}\text { MWRA Outfall Site, } \\
\text { Massachusetts Bay }\end{array}$ & $\begin{array}{l}42^{\circ} 23.1^{\prime} \mathrm{N} \\
70^{\circ} 49.3^{\prime} \mathrm{W} \\
\end{array}$ & $15 \mathrm{~m}$ & $\begin{array}{c}1992-2003 \\
(\mathrm{n}=9)\end{array}$ \\
\hline & Cape Cod Bay & $\begin{array}{l}41^{\circ} 55.5^{\prime} \mathrm{N} \\
70^{\circ} 20.0^{\prime} \mathrm{W}\end{array}$ & $15 \mathrm{~m}$ & $\begin{array}{c}1998-2003 \\
(\mathrm{n}=5)\end{array}$ \\
\hline \multirow[t]{7}{*}{ NOAA } & $\begin{array}{l}\text { Nahant Bay, } \\
\text { Massachusetts Bay } \\
\text { (MBNB) }\end{array}$ & $\begin{array}{l}42.419833 \\
-70.907167\end{array}$ & $\begin{array}{l}\text { Inter } \\
\text { tidal }\end{array}$ & 8 \\
\hline & $\begin{array}{l}\text { Deer Island, } \\
\text { Boston Harbor (BHDI) }\end{array}$ & $\begin{array}{c}42.357333 \\
-70.973000\end{array}$ & $\begin{array}{l}\text { Inter } \\
\text { tidal }\end{array}$ & $\begin{array}{c}1986-2003 \\
(n=13)\end{array}$ \\
\hline & $\begin{array}{l}\text { Dorchester Bay, Boston } \\
\text { Harbor (BHDB) }\end{array}$ & $\begin{array}{l}42.302167 \\
-71.036333\end{array}$ & $\begin{array}{l}\text { Inter } \\
\text { tidal }\end{array}$ & $\begin{array}{c}1986-2003 \\
(n=12)\end{array}$ \\
\hline & $\begin{array}{l}\text { Hingham Bay, Boston } \\
\text { Harbor (BHHB) }\end{array}$ & $\begin{array}{l}42.276000 \\
-70.883333 \\
\end{array}$ & $\begin{array}{l}\text { Inter } \\
\text { tidal }\end{array}$ & 13 \\
\hline & $\begin{array}{l}\text { Brewster Island, } \\
\text { Massachusetts Bay } \\
\text { (BHBI) }\end{array}$ & $\begin{array}{l}42.343167 \\
-70.878333\end{array}$ & $\begin{array}{l}\text { Inter } \\
\text { tidal }\end{array}$ & $\begin{array}{l}1986-2003 \\
(\mathrm{n}=14)\end{array}$ \\
\hline & $\begin{array}{l}\text { North River, } \\
\text { Massachusetts Bay } \\
\text { (MBNR) }\end{array}$ & $\begin{array}{l}42.160333 \\
-70.742500\end{array}$ & $\begin{array}{l}\text { Inter } \\
\text { tidal }\end{array}$ & 7 \\
\hline & $\begin{array}{l}\text { Clarks Island, Duxbury } \\
\text { Bay (DBCI) }\end{array}$ & $\begin{array}{l}42.013667 \\
-70.636500\end{array}$ & $\begin{array}{l}\text { Inter } \\
\text { tidal }\end{array}$ & 11 \\
\hline
\end{tabular}


Table 2. Chemicals measured under the Mussel Watch and MWRA monitoring programs.

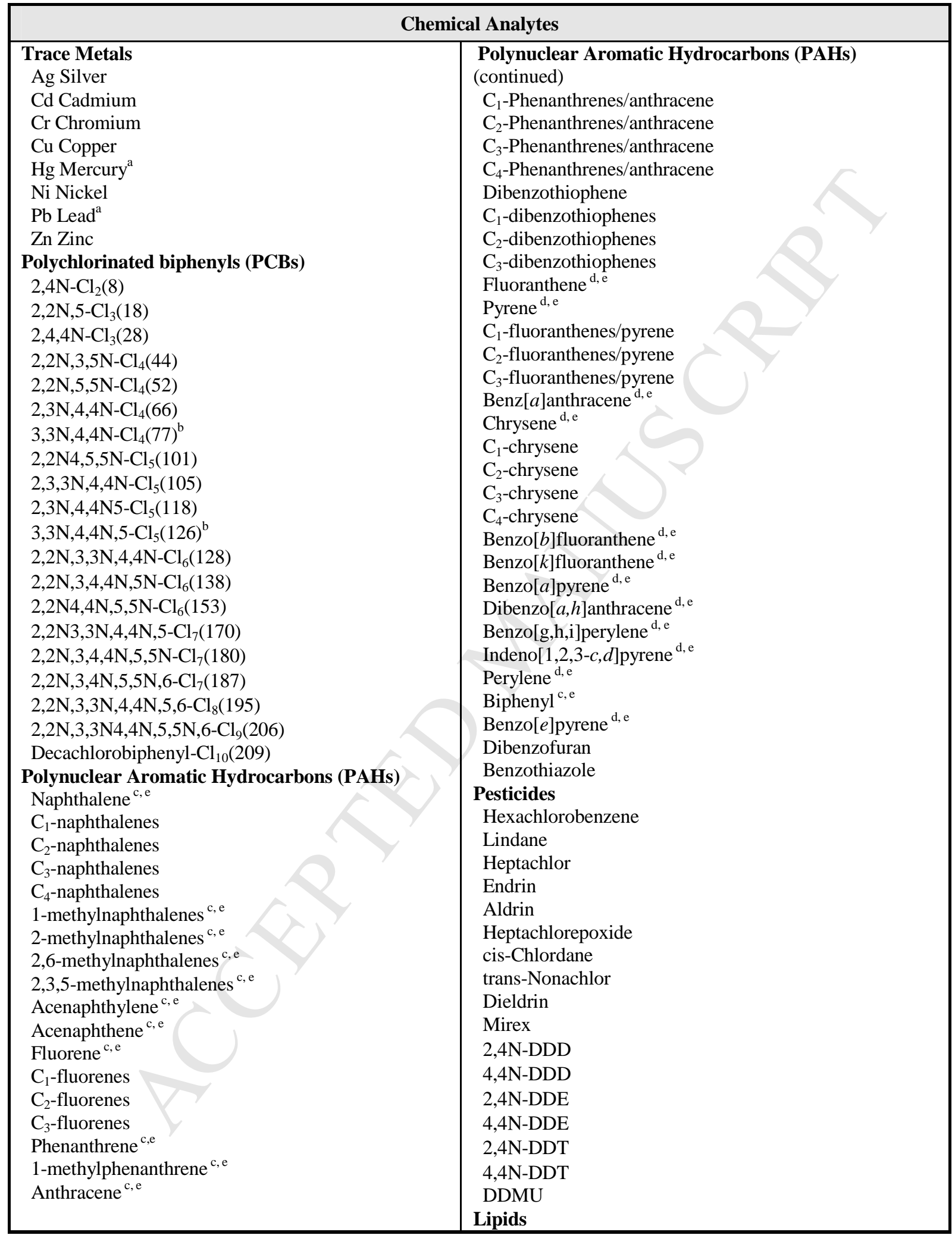

${ }^{\mathrm{a}}$ MWRA measures this metal

${ }^{\mathrm{b}}$ MWRA quantifies these congeners although they forma small fraction of the total PCBs

c. Included in LMWPAH total

${ }^{\text {d. Included in HMWPAH total }}$

e. Included in total PAH 
Table 3. Spearman rank correlation coefficient, trend direction, and significance level recorded in blue mussels sampled in the Boston Harbor and Massachusetts Bay region between 1986 and 2003 as collected by NOAA (from O'Connor and Lauenstein, 2006) and by MWRA.

\begin{tabular}{|c|c|c|c|c|c|c|c|c|c|c|}
\hline Specific Location & Lindane & \begin{tabular}{|l|} 
Total \\
Clordane
\end{tabular} & $\begin{array}{l}\text { Total } \\
\text { DDT }\end{array}$ & \begin{tabular}{|l} 
Total \\
Dieldrin
\end{tabular} & $\begin{array}{l}\text { Total } \\
\text { PCB }\end{array}$ & $\begin{array}{l}\text { LMW } \\
\text { PAH }\end{array}$ & $\begin{array}{l}\text { HMW } \\
\text { PAH }\end{array}$ & $\begin{array}{l}\text { Total } \\
\text { PAH }\end{array}$ & Mercury & Lead \\
\hline \multicolumn{11}{|c|}{ MWRA } \\
\hline Cape Cod Bay & $\begin{array}{c}0.400 \\
(0.505)\end{array}$ & $\begin{array}{c}-.900 \\
(0.037) \\
\nabla *\end{array}$ & $\begin{array}{c}-.800 \\
(0.104)\end{array}$ & $\begin{array}{c}-.500 \\
(0.391)\end{array}$ & $\begin{array}{c}-.600 \\
(0.285)\end{array}$ & $\begin{array}{c}-.600 \\
(0.285)\end{array}$ & $\begin{array}{c}0.100 \\
(0.873)\end{array}$ & $\begin{array}{c}-.100 \\
(0.873)\end{array}$ & $\begin{array}{c}0.800 \\
(0.104)\end{array}$ & $\begin{array}{l}-.400 \\
(0.505)\end{array}$ \\
\hline $\begin{array}{l}\text { Deer Island Light, Boston } \\
\text { Harbor (DIL) }\end{array}$ & $\begin{array}{c}-.218 \\
(0.497)\end{array}$ & $\begin{array}{c}-.510 \\
(0.090) \\
\nabla\end{array}$ & $\begin{array}{c}-.441 \\
(0.152)\end{array}$ & $\begin{array}{l}-.308 \\
(0.331)\end{array}$ & $\begin{array}{c}0.238 \\
(0.457)\end{array}$ & $\begin{array}{c}-.930 \\
(<.001) \\
\boldsymbol{\nabla} *\end{array}$ & $\begin{array}{c}-.874 \\
(<.001) \\
\nabla *\end{array}$ & $\begin{array}{c}-.909 \\
(<.001) \\
\nabla *\end{array}$ & $\begin{array}{c}-.188 \\
(0.603)\end{array}$ & $\begin{array}{c}-.555 \\
(0.077) \\
\nabla\end{array}$ \\
\hline $\begin{array}{l}\text { Inner Harbor, Boston } \\
\text { Inner Harbor (IH) }\end{array}$ & $\begin{array}{c}0.066 \\
(0.831)\end{array}$ & $\begin{array}{l}-.165 \\
(0.590)\end{array}$ & $\begin{array}{c}-.236 \\
(0.437) \\
\end{array}$ & $\begin{array}{c}-.203 \\
(0.505)\end{array}$ & $\begin{array}{c}-.242 \\
(0.426)\end{array}$ & \begin{tabular}{|c|}
-.176 \\
$(0.566)$ \\
\end{tabular} & \begin{tabular}{|c|}
-.352 \\
$(0.239)$ \\
\end{tabular} & $\begin{array}{l}-.330 \\
(0.271) \\
\end{array}$ & $\begin{array}{c}0.333 \\
(0.347)\end{array}$ & $\begin{array}{r}0.318 \\
(0.340) \\
\end{array}$ \\
\hline $\begin{array}{l}\text { MWRA Outfall Site, } \\
\text { Massachusetts Bay } \\
\text { (OSM) }\end{array}$ & $\begin{array}{c}0.587 \\
(0.058) \\
\Delta\end{array}$ & $\begin{array}{c}0.600 \\
(0.051) \\
\mathbf{\Delta}\end{array}$ & $\begin{array}{c}-.264 \\
(0.433)\end{array}$ & $\begin{array}{c}0.127 \\
(0.709)\end{array}$ & $\begin{array}{c}-.173 \\
(0.612)\end{array}$ & $\begin{array}{c}0.127 \\
(0.709)\end{array}$ & $\begin{array}{c}0.500 \\
(0.117)\end{array}$ & $\begin{array}{c}0.627 \\
(0.039) \\
\Delta *\end{array}$ & $\begin{array}{c}0.370 \\
(0.293)\end{array}$ & $\begin{array}{l}-.418 \\
(0.229)\end{array}$ \\
\hline \multicolumn{11}{|c|}{ NOAA } \\
\hline $\begin{array}{l}\text { Nahant Bay, } \\
\text { Massachusetts Bay }\end{array}$ & & $\boldsymbol{\nabla} *$ & $\boldsymbol{\nabla} *$ & & & & & & & \\
\hline $\begin{array}{l}\text { Deer Island, Boston } \\
\text { Harbor }\end{array}$ & $\nabla$ & $\nabla *$ & $\nabla$ & $\nabla$ & & $\nabla *$ & & $\nabla$ & $\nabla *$ & $\nabla$ \\
\hline $\begin{array}{l}\text { Dorchester Bay, Boston } \\
\text { Harbor }\end{array}$ & $\boldsymbol{\nabla} *$ & $\boldsymbol{\nabla} *$ & & $\boldsymbol{\nabla} *$ & & & & & & $\boldsymbol{\nabla} *$ \\
\hline $\begin{array}{l}\text { Hingham Bay, Boston } \\
\text { Harbor }\end{array}$ & & $\nabla *$ & & & & & & & & \\
\hline $\begin{array}{l}\text { Brewster Island, Western } \\
\text { Massachusetts Bay }\end{array}$ & & $\boldsymbol{\nabla} *$ & $\boldsymbol{\nabla}$ * & $\boldsymbol{\nabla}$ & & & & & & \\
\hline $\begin{array}{l}\text { North River, } \\
\text { Massachusetts Bay }\end{array}$ & $\boldsymbol{\nabla} *$ & $\nabla *$ & $\nabla$ * & $\nabla *$ & $\boldsymbol{\nabla} *$ & & & & & $\nabla$ \\
\hline $\begin{array}{l}\text { Clarks Island, Duxbury } \\
\text { Bay }\end{array}$ & & & $\nabla *$ & $\nabla *$ & $\nabla *$ & & & & & \\
\hline
\end{tabular}

$\boldsymbol{\nabla}=$ Significantly decreasing correlation at a $10 \%$ significance level

$\boldsymbol{\nabla} *=$ Significantly decreasing correlation at a $5 \%$ significance level

$\boldsymbol{\Delta}=$ Significantly increasing correlation at a $10 \%$ significance level

$\boldsymbol{\Delta} *=$ Significantly increasing correlation at a 5\% significance level 
Table 4. Summary of sen trend estimates for trends in MWRA and Mussel Watch Deer Island emissions with related $\mathrm{p}$-values (*=significant at $5 \%$ level of significance).

\begin{tabular}{|c|c|c|c|c|c|c|}
\hline Program & Site & Mercury & $\begin{array}{l}\text { Total } \\
\text { Chlor }\end{array}$ & Total DDT & $\begin{array}{l}\text { Total } \\
\text { PAH }\end{array}$ & $\begin{array}{l}\text { Total } \\
\text { PCB }\end{array}$ \\
\hline \multirow[t]{4}{*}{ MWRA } & Cape Cod Bay & $\begin{array}{l}0.011 \\
(0.14)\end{array}$ & $\begin{array}{l}-0.831 \\
(0.05) *\end{array}$ & $\begin{array}{r}-1.382 \\
(0.14)\end{array}$ & $\begin{array}{r}-0.482 \\
(1.00)\end{array}$ & $\begin{array}{l}-1.62 \\
(0.33)\end{array}$ \\
\hline & $\begin{array}{l}\text { Deer Island Light, } \\
\text { Boston Harbor }\end{array}$ & $\begin{array}{c}0 \\
(0.93)\end{array}$ & $\begin{array}{l}-0.947 \\
(0.13)\end{array}$ & $\begin{array}{l}-2.481 \\
(0.10) *\end{array}$ & $\begin{array}{l}-88.385 \\
(<.01) *\end{array}$ & $\begin{array}{l}1.857 \\
(0.41)\end{array}$ \\
\hline & $\begin{array}{l}\text { Inner Harbor, Boston } \\
\text { Inner Harbor }\end{array}$ & $\begin{array}{l}0.006 \\
(0.42)\end{array}$ & $\begin{array}{l}-0.632 \\
(0.54)\end{array}$ & $\begin{array}{r}-1.667 \\
(0.54)\end{array}$ & $\begin{array}{c}-59.543 \\
(0.33)\end{array}$ & $\begin{array}{l}-6.204 \\
(0.46)\end{array}$ \\
\hline & $\begin{array}{l}\text { MWRA Outfall Site, } \\
\text { Massachusetts Bay }\end{array}$ & $\begin{array}{l}0.003 \\
(0.33)\end{array}$ & $\begin{array}{l}0.924 \\
(0.10)\end{array}$ & $\begin{array}{l}-0.85 \\
(0.39)\end{array}$ & $\begin{array}{l}20.404 \\
(0.04) *\end{array}$ & $\begin{array}{r}-1.436 \\
(0.59)\end{array}$ \\
\hline \multirow[t]{3}{*}{ NOAA } & $\begin{array}{l}\text { Brewster Island, } \\
\text { Western Massachusetts } \\
\text { Bay }\end{array}$ & $\begin{array}{l}-0.008 \\
(0.38)\end{array}$ & $\begin{array}{c}-2.018 \\
(<.01) *\end{array}$ & $\begin{array}{c}-4.406 \\
(0.01) *\end{array}$ & $\begin{array}{r}-27.31 \\
(0.62)\end{array}$ & $\begin{array}{r}-5.864 \\
(0.25)\end{array}$ \\
\hline & $\begin{array}{l}\text { Deer Island, Boston } \\
\text { Harbor }\end{array}$ & $\begin{array}{l}-0.009 \\
(0.06) *\end{array}$ & $\begin{array}{l}-2.224 \\
(0.01) *\end{array}$ & $\begin{array}{l}-4.092 \\
(0.07) *\end{array}$ & $\begin{array}{r}-171.285 \\
(0.01) *\end{array}$ & $\begin{array}{r}-3.911 \\
(0.33)\end{array}$ \\
\hline & $\begin{array}{l}\text { Dorchester Bay, Boston } \\
\text { Harbor }\end{array}$ & $\begin{array}{l}-0.001 \\
(0.73)\end{array}$ & $\begin{array}{l}-3.407 \\
(<.01) *\end{array}$ & $\begin{array}{l}-7.68 \\
(0.17)\end{array}$ & $\begin{array}{r}-123.962 \\
(0.05) *\end{array}$ & $\begin{array}{c}-30.184 \\
(0.13)\end{array}$ \\
\hline \multirow[t]{3}{*}{$\begin{array}{l}\text { NOAA } \\
(1991- \\
2003)\end{array}$} & $\begin{array}{l}\text { Brewster Island, } \\
\text { Western Massachusetts } \\
\text { Bay }\end{array}$ & $\begin{array}{l}-0.01 \\
(0.12)\end{array}$ & $\begin{array}{r}-1.912 \\
(0.40)\end{array}$ & $\begin{array}{l}-3.889 \\
(0.21)\end{array}$ & $\begin{array}{r}1.564 \\
(0.3)\end{array}$ & $\begin{array}{r}-5.273 \\
(0.68)\end{array}$ \\
\hline & $\begin{array}{l}\text { Deer Island, Boston } \\
\text { Harbor }\end{array}$ & $\begin{array}{c}-0.01 \\
(0.08) *\end{array}$ & $\begin{array}{l}-1.864 \\
(0.08) *\end{array}$ & $\begin{array}{l}-3.488 \\
(0.08) *\end{array}$ & $\begin{array}{c}-132.894 \\
(0.8)\end{array}$ & $\begin{array}{l}-3.557 \\
(0.62)\end{array}$ \\
\hline & $\begin{array}{l}\text { Dorchester Bay, Boston } \\
\text { Harbor }\end{array}$ & $\begin{aligned}-0.002 \\
(0.54)\end{aligned}$ & $\begin{array}{c}-3.1 \\
(0.01) *\end{array}$ & $\begin{array}{c}-7.95 \\
(0.05) *\end{array}$ & $\begin{array}{c}-140.889 \\
(0.18)\end{array}$ & $\begin{array}{l}-42.935 \\
(0.01) *\end{array}$ \\
\hline
\end{tabular}




\section{ACCEPTED MANUSCRIPT}

Table 5. Comparison of the relationship between chemical measurements observed at the MWRA and Mussel Watch Deer Island stations. Correlations between measurements made during the same year are assessed through the Spearman correlation. Sen-Adichie assesses whether the trends in the data are not parallel over time and is calculated for all years as well as for 1991-2003.

\begin{tabular}{|l|c|c|c|}
\hline \multicolumn{1}{|c|}{ Chemical } & $\begin{array}{c}\text { Spearman } \\
\text { Correlation } \\
\text { p-Value }\end{array}$ & $\begin{array}{c}\text { Sen- } \\
\text { Adichie } \\
\text { p-Value }\end{array}$ & $\begin{array}{c}\text { Sen- } \\
\text { Adichie } \\
\text { p-Value } \\
\text { (Post 1990) }\end{array}$ \\
\hline Mercury & 1.00 & 0.19 & 0.09 \\
\hline Total Chlor & 0.40 & 0.07 & 0.29 \\
\hline Total DDT & 0.87 & 0.16 & 0.75 \\
\hline Total PAH & 0.79 & 0.16 & 0.28 \\
\hline Total PCB & 0.96 & 0.31 & 0.37 \\
\hline
\end{tabular}


Table 6. Table 6. Comparison of Contaminants in Mussel Tissue from Other Areas. The means and standard deviations of the stations for 1998 GulfWatch stations are compared to the 1998-2008 1998.

\begin{tabular}{|c|c|c|c|c|c|c|c|}
\hline Location & \multicolumn{2}{|c|}{ Boston Inner Harbor } & \multicolumn{2}{|c|}{ Outer Harbor } & \multicolumn{2}{|c|}{ Cape Cod } & \multirow{2}{*}{$\begin{array}{c}\text { Maine } \\
\text { MWRA }\end{array}$} \\
\hline Program & GW & MWRA & GW & MWRA & GW & MWRA & \\
\hline Station & MAIH & IH & MALI & DIL & MASA & CCB & SP \\
\hline Year & 1998 & $1998-2000$ & 1999 & $1998-2000$ & $1998-2000$ & $1998-2000$ & $2002-2003$ \\
\hline$n$ & 4 & 15 & 5 & 10 & 12 & 16 & 10 \\
\hline tPAH & $\begin{array}{c}3333 \pm \\
223^{\mathrm{a}} \\
\end{array}$ & $2396 \pm 322$ & $\begin{array}{c}394 \pm \\
51^{\mathrm{a}}\end{array}$ & $351 \pm 189$ & $44 \pm 26^{\mathrm{a}}$ & $46 \pm 8$ & $69 \pm 7$ \\
\hline tPCB & $740 \pm 39^{b}$ & $515 \pm 69$ & $\begin{array}{c}166 \pm \\
11^{\mathrm{b}}\end{array}$ & $188 \pm 38$ & $41 \pm 12^{b}$ & $48 \pm 1$ & $18 \pm 4$ \\
\hline tDDT & $106 \pm 14$ & $89 \pm 10$ & $22 \pm 2$ & $35 \pm 4$ & $30 \pm 7$ & $17 \pm 1$ & $7 \pm 0.06$ \\
\hline Mercury & $\begin{array}{c}0.55 \pm \\
0.02 \\
\end{array}$ & $0.13 \pm 0.04$ & $\begin{array}{c}0.4 \pm \\
0.1 \\
\end{array}$ & $0.13 \pm 0.04$ & $0.42 \pm 0.07^{\mathrm{c}}$ & $0.06 \pm 0.01$ & $0.14 \pm 0.03$ \\
\hline Lead & $32.3 \pm 3.3$ & $7.3 \pm 5.1$ & $\begin{array}{c}5.9 \pm \\
0.5 \\
\end{array}$ & $5.2 \pm 2.4$ & $2.8 \pm 0.6^{\mathrm{c}}$ & $1.6 \pm 0.5$ & $2.0 \pm 0.5$ \\
\hline \multicolumn{8}{|c|}{$\begin{array}{l}\text { Source of Gulfwatch data: http://www.gulfofmaine.org/gulfwatch/results.asp } \\
\text { GW = Gulfwatch } \\
\text { Units for organic contaminants are ng/g dry weight. } \\
\text { Units for metals are } \mu \mathrm{g} / \mathrm{g} \text { dry weight. } \\
\text { a } \text { TPAH value is Total } 24 \text { PAHs. } \\
{ }^{\mathrm{b}} \text { GulfWatch TPCB includes additional congeners }(5,15,90,95,132,190,208) \text {. } \\
\text { TDDT is the sum of } 6 \text { congeners. }\end{array}$} \\
\hline
\end{tabular}




\section{Figures}

Figure 1. NOAA Mussel Watch stations and Massachusetts Water Resources Authority caged mussel deployment sites in the Massachusetts Bay and Boston Harbor.

Figure 2. Trends in total Chlordane in the Boston Harbor and Massachusetts Bay area 1986 through 2003. The dashed line is the best fit trend; the vertical line delineates when the outfall was transferred offshore in September 2000.

Figure 3. Trends in total PCB in the Boston Harbor and Massachusetts Bay area: 1986 through 2003. Reported Mussel Watch tPCB data has been halved to make the totals consistent with the reported MWRA data. MWRA adopted the practice of reporting only measurable PCB congeners to ensure its compliance with data quality indicator thresholds are strictly analytically based. The dashed line is the best fit trend; the vertical line delineates when the outfall was transferred offshore in September 2000.

Figure 4. Trends in total DDT in the Boston Harbor and Massachusetts Bay area: 1986 through 2003. The dashed line is the best fit trend; the vertical line delineates when the outfall was transferred offshore in September 2000.

Figure 5. Trends in total PAH in the Boston Harbor and Massachusetts Bay area: 1986 through 2003. The dashed line is the best fit trend; the vertical line delineates when the outfall was transferred offshore in September 2000.

Figure 6. Trends in mercury in the Boston Harbor and Massachusetts Bay area: 1986 through 2003. The dashed line is the best fit trend; the vertical line delineates when the outfall was transferred offshore in September 2000.

Figure 7. Comparison of pre- and post- deployment mercury in MWRA caged mussels. Error bars are the standard deviation $\left(95^{\text {th }}\right.$ Confidence Interval $)$ of the replicate composite caged mussel samples from each station in a given sampling year; in many cases the error bar is within the symbol size. 
Figure 1

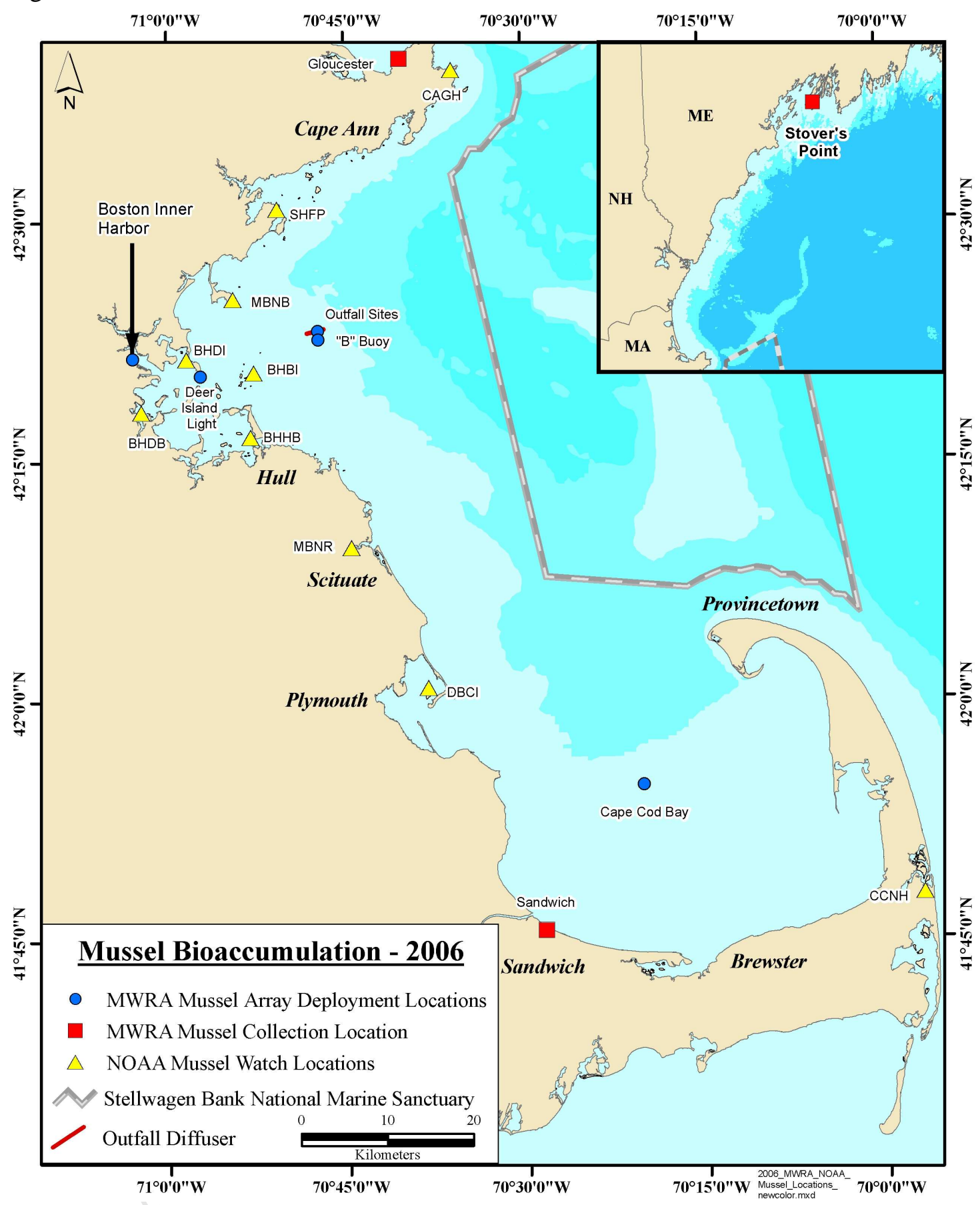


Figure 2
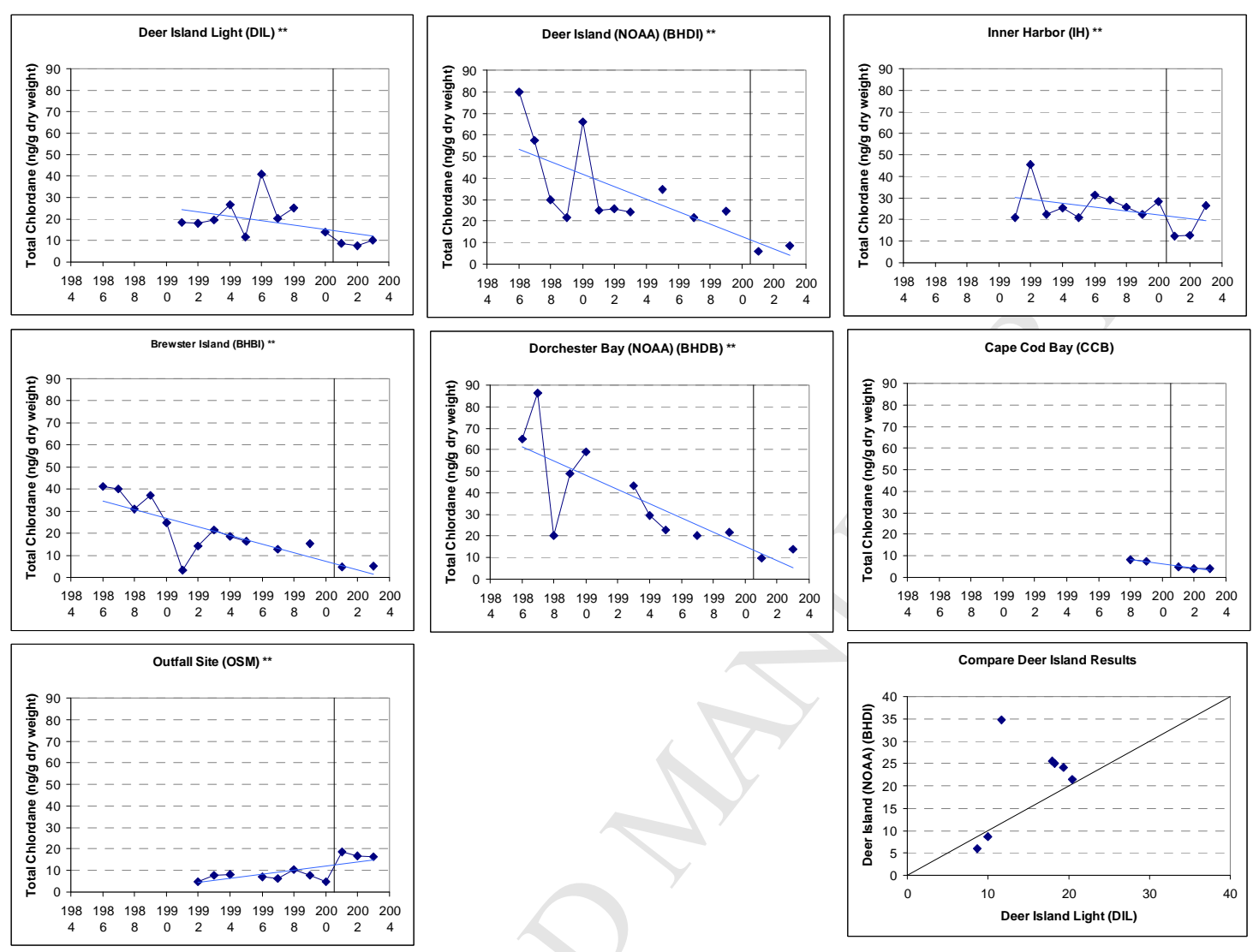
Figure 3 PCB
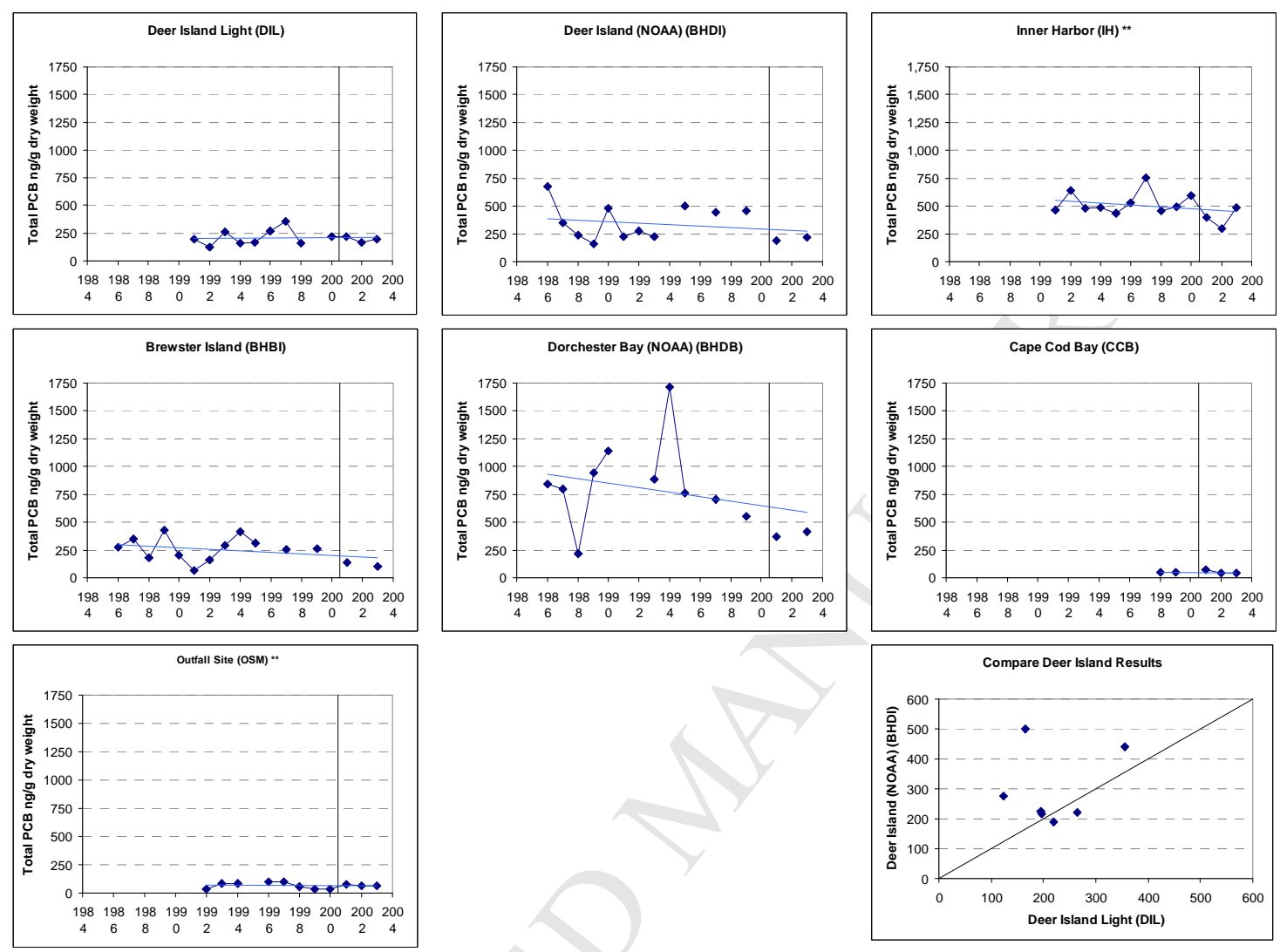
Figure 4 DDT
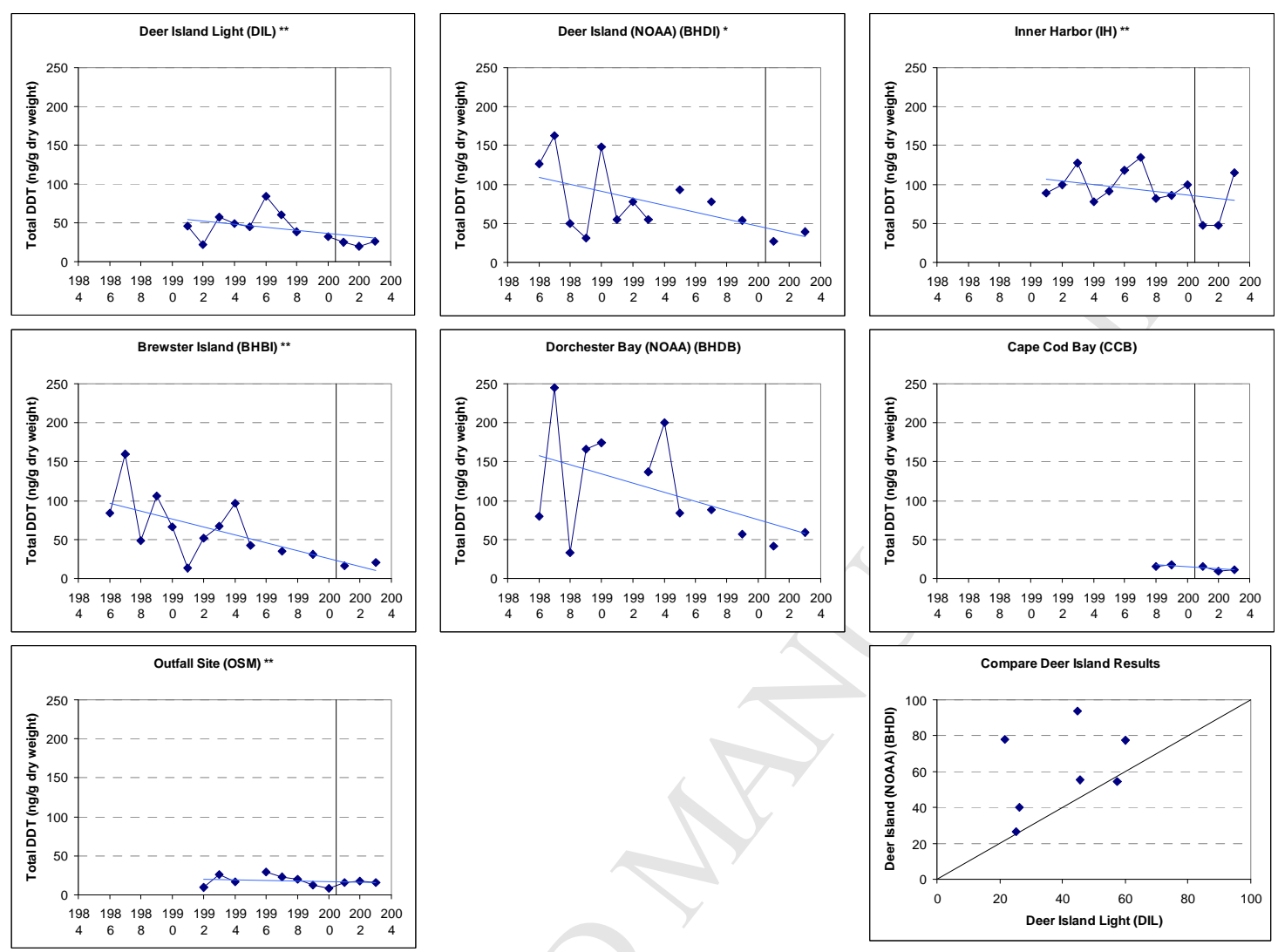
Figure 5 PAH
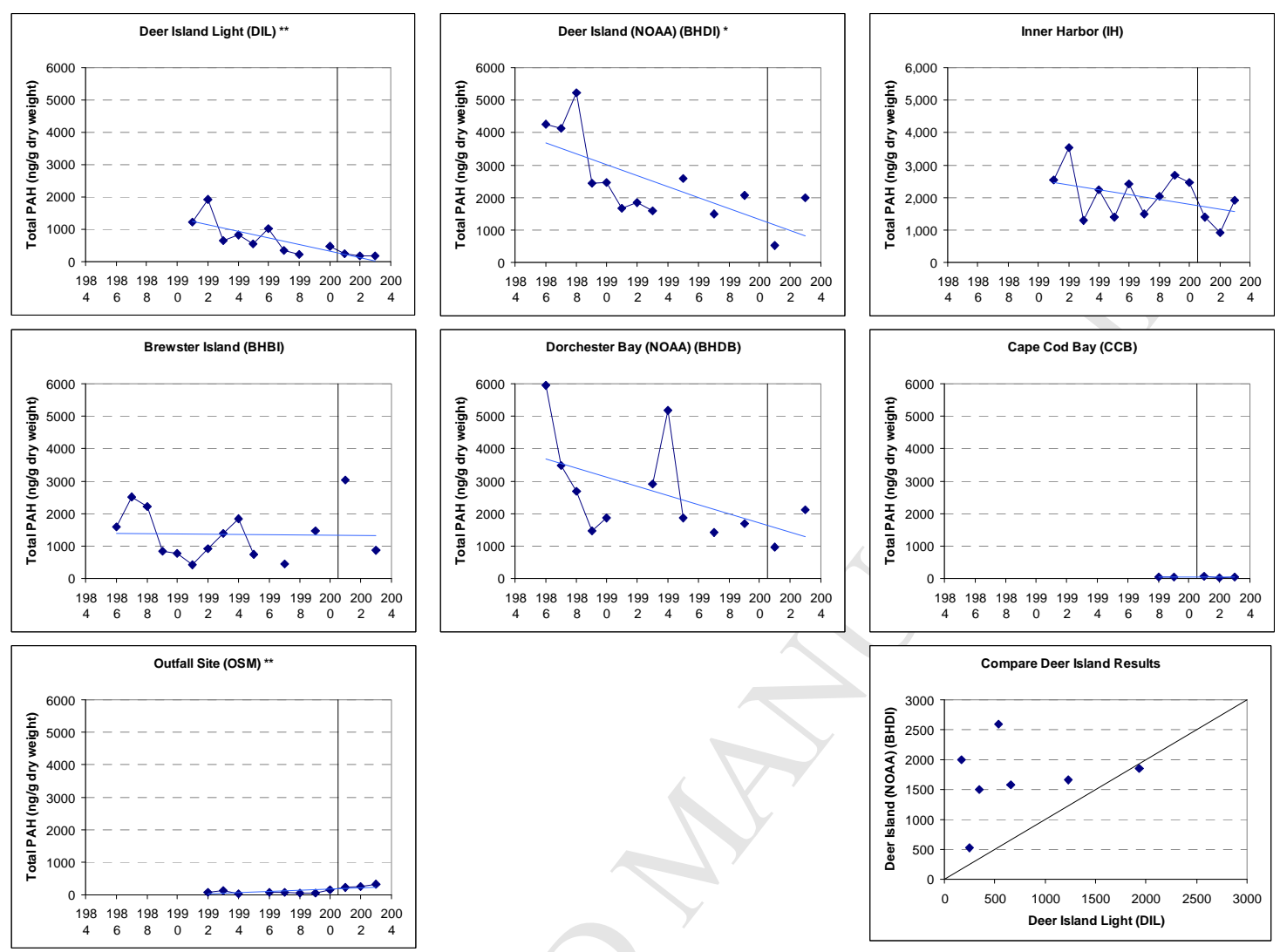
Figure 6
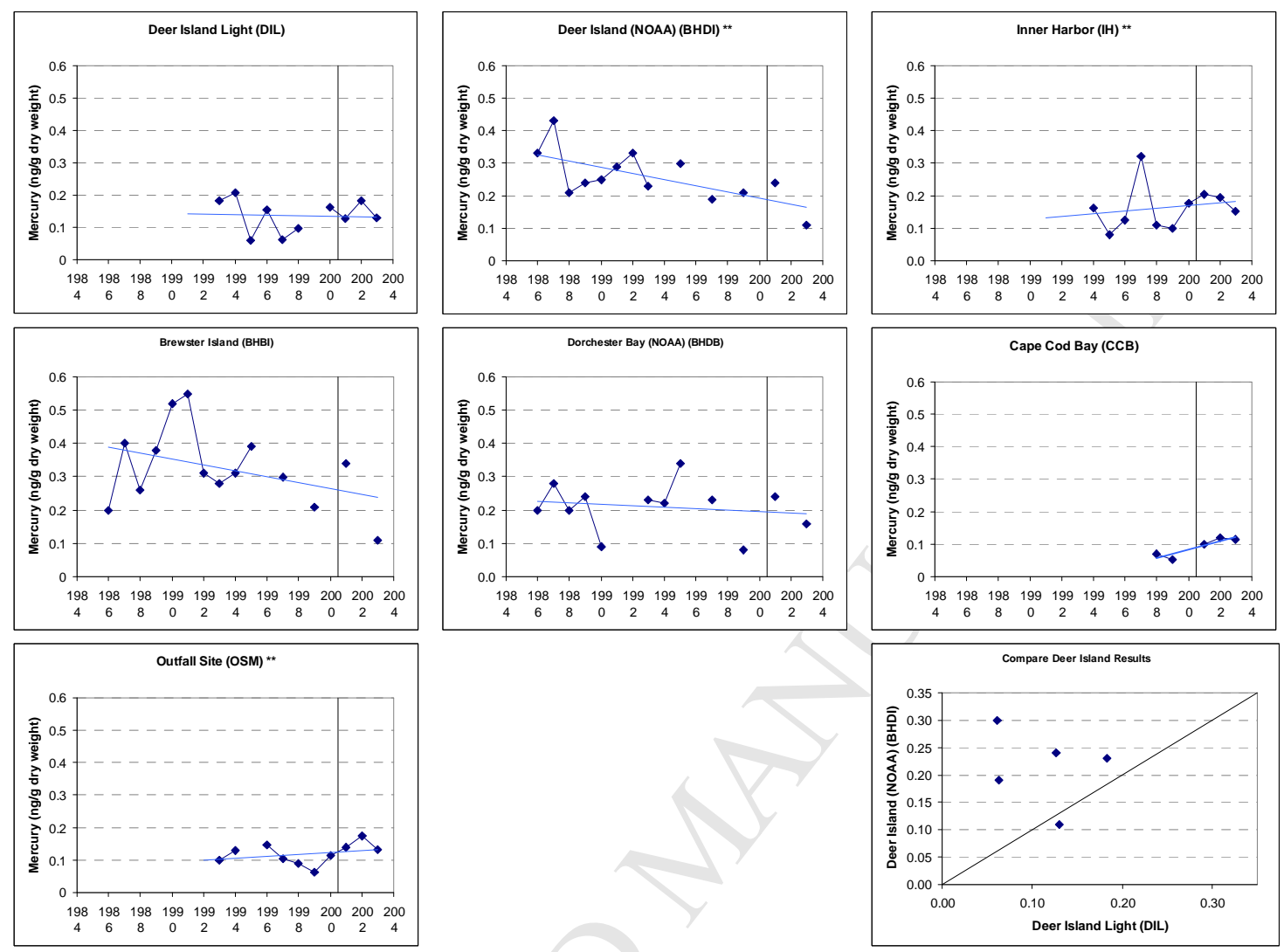
Figure 7

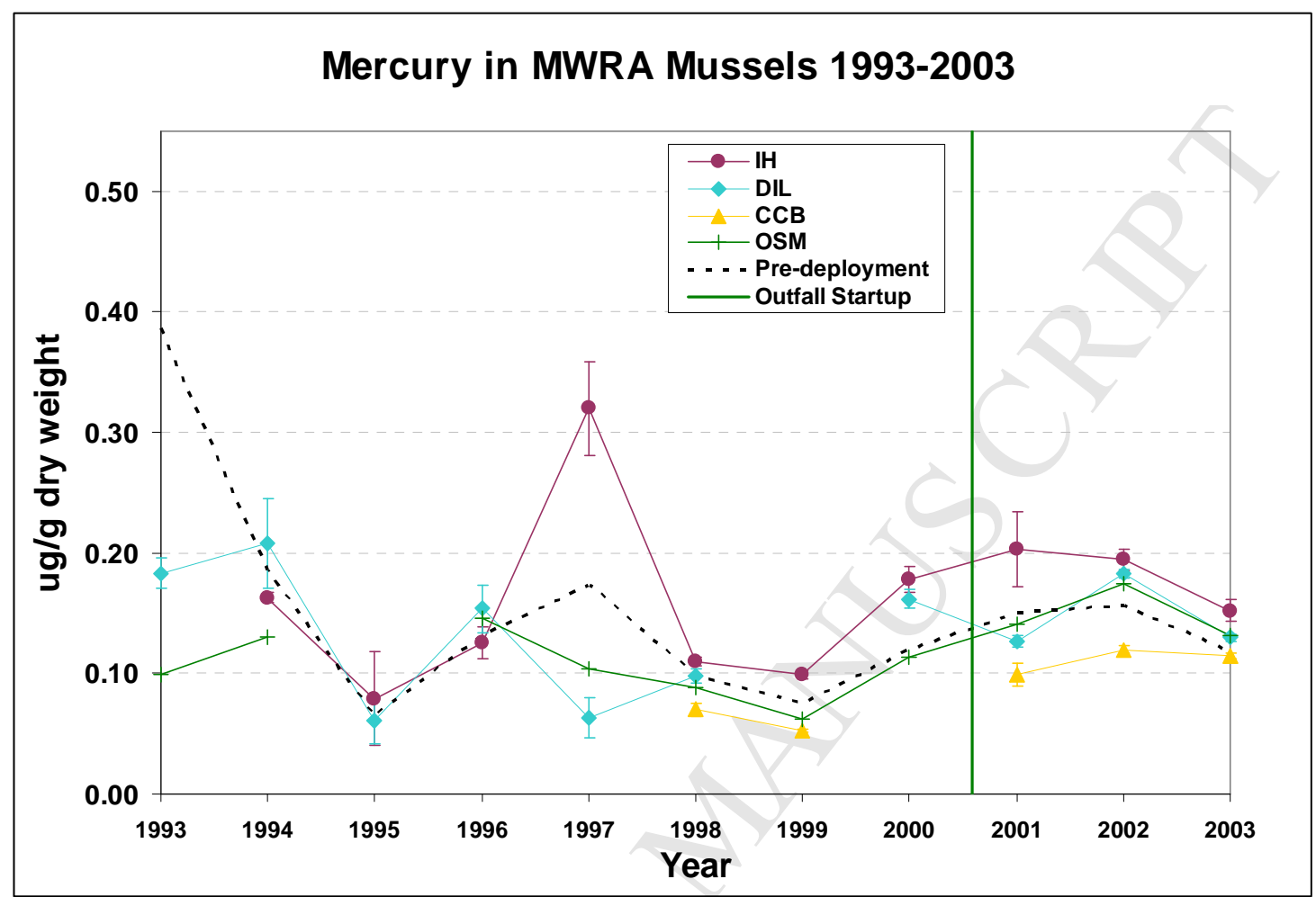

